\title{
Isolation of Paraclostridium CR4 from sugarcane bagasse and its evaluation in the bioconversion of lignocellulosic feedstock into hydrogen by monitoring cellulase gene expression
}

\author{
Camila Abreu B. Silva Rabelo ${ }^{a, *}$, Cintia Hiromi Okino ${ }^{\mathrm{b}}$, \\ Isabel Kimiko Sakamoto ${ }^{a}$, Maria Bernadete Amâncio Varesche ${ }^{a}$ \\ a Laboratory of Biological Processes, Department of Hydraulics and Sanitation, Engineering School of São Carlos, University of São Paulo (EESC - USP) Campus II, São Carlos, SP CEP 13563-120, Brazil \\ b Embrapa Pecuria Sudeste, Rod Washington Luiz, Km 234, Fazenda Canchim, PO Box 339, São Carlos, SP, Brazil
}

\section{H I G H L I G H T S}

Paraclostridium was identified as autochthonous bacteria from sugarcane bagasse.

Paraclostridium produced $\mathrm{H}_{2}$ from glucose, cellulose and sugarcane bagasse.

The substrate type regulated the formation of the final product (acetic/butyric). There was cell growth during all stages of $\mathrm{H}_{2}$ production.

The cellulase family protein expression was regulated by soluble sugars.

\section{G R A P H I C A L A B S T RAC T}

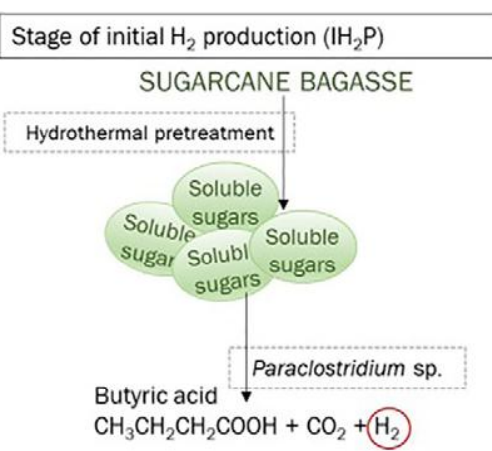

$\mathrm{CH}_{3} \mathrm{CH}_{2} \mathrm{CH}_{2} \mathrm{COOH}+\mathrm{CO}_{2}+\mathrm{H}_{2}$

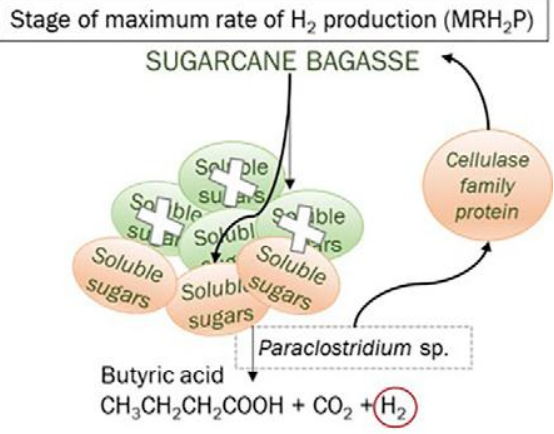

$\mathrm{CH}_{3} \mathrm{CH}_{2} \mathrm{CH}_{2} \mathrm{COOH}+\mathrm{CO}_{2}+\mathrm{H}_{2}$

\section{a r t icle info}

\section{Article history:}

Received 28 November 2019

Received in revised form 20 January 2020

Accepted 21 January 2020

Available online 24 January 2020

Editor: Frederic Coulon

\section{Keywords:}

Autochthonous bacteria

Hydrolysis

Fermentation

qPCR

Reference gene

\begin{abstract}
a bs t r a c t
Bioconversion of sugarcane bagasse $(\mathrm{SCB})$ into hydrogen $\left(\mathrm{H}_{2}\right)$ and organic acids was evaluated using a biomolecular approach to monitor the quantity and expression of the cellulase (Cel) gene. Batch reactors at $37^{\circ} \mathrm{C}$ were operated with Paraclostridiumsp. ( $10 \% \mathrm{v} / \mathrm{v}$ ) and different substrates $(5 \mathrm{~g} / \mathrm{L})$ : glucose, cellulose and SCB in natura and pre-heat treated and hydrothermally. $\mathrm{H}_{2}$ production from glucose was $162.4 \mathrm{~mL}$ via acetic acid $(2.9 \mathrm{~g} / \mathrm{L})$ and $78.4 \mathrm{~mL}$ from cellulose via butyric acid $(2.9 \mathrm{~g} / \mathrm{L}) . \mathrm{H}_{2}$ production was higher in hydrothermally pretreated $\mathrm{SCB}$ reactors $(92.0 \mathrm{~mL})$, heat treated $(62.5 \mathrm{~mL})$, when compared to in natura $\mathrm{SCB}(51.4 \mathrm{~mL})$. Butyric acid $(5.8,4.9$ and $4.0 \mathrm{~g} / \mathrm{L}$ ) was the main acid observed in hydrothermally, thermally pretreated, and in natura SCB, respectively. In the reactors with cellulose and reactors with hydrothermally pretreated SCB, the Cel gene copy number 3 and $2 \log$ were higher, respectively, during the stage of maximum $\mathrm{H}_{2}$ production rate, when compared to the initial stage. Differences in Cel gene expression were observed according to the concentration of soluble sugars in the reaction medium. That is, there was no gene expression at the initial phase of the experiment using SCB with $2.6 \mathrm{~g} / \mathrm{L}$ of sugars and increase of $2.2 \log$ in gene expression during the phases with soluble sugars of b1.4 $\mathrm{g} / \mathrm{L}$. (c) 2020 Elsevier B.V. All rights reserved.
\end{abstract}

\footnotetext{
* Corresponding author.

E-mail address: camilasilva@sc.usp.br (C.A.B. Silva Rabelo).
} 


\section{Introduction}

Lignocellulosic material has been used as an alternative substrate for sustainable production of biofuels such as hydrogen (Ratti et al., 2015; Soares et al., 2017; Rabelo et al., 2018b), methane (Guo et al., 2014; Tantayotai et al., 2017) and ethanol (Kumar et al., 2008; Rabelo et al., 2011). Some of the main advantages of using these materials are their wide availability and high carbon content. In addition, the use of lignocellulosic material adds waste reduction to clean energy generation (Shrestha et al., 2017; Ahmad et al., 2018).

According to its origin, lignocellulosic material can be obtained from the processing of forest residues (mainly wood), agricultural residues (soybean, rice and sugarcane, among others) and urban and industrial residues (solid or liquid). Brazil is the largest producer of sugarcane in the world and 620.8 million tons of sugarcane were produced in the 2018/19 harvest, and later about 0.2 million tons of sugarcane bagasse (SCB) (UNICA, 2019). Although the traditional use of SCB is a substrate for boiler combustion within the plants themselves, there is surplus that can be made available for hydrogen production.

The effective degradation of lignocellulosic materials, requires synergistic stages of cellulolytic enzyme production, polysaccharide hydrolysis and sugar fermentation. In this process, the speed and yield of the end products are related to the initial hydrolysis (Saratale et al., 2008; Juturu and $\mathrm{Wu}, 2014$ ). Hydrolysis is generally limited by the complex structure of materials, including cellulose crystallinity, particle size and the presence of associated materials such as hemicellulose and lignin (Binod et al., 2011; Galbe and Zacchi, 2012).

Cellulolytic anaerobic bacteria can be obtained from ruminal fluid (Deng et al., 2017), from invertebrates (Gupta et al., 2012) and mollusks (Muñoz et al., 2014), soil (Talia et al., 2012), decomposition of grass (Desvaux, 2005) and sugarcane bagasse (Ratti et al., 2015; Rabelo et al., 2018a). Ratti et al. (2015) and Rabelo et al. (2018a) identified autochthonous cellulolytic bacteria from sugarcane bagasse and similar to Clostridium, Tepidimicrobia, and Paenibacillus. Both authors used this source of autochthonous bacteria as an inoculum for the bioconversion of pre-treated sugarcane bagasse into hydrogen and organic acids.

Cellulolytic, anaerobic and gram-positive bacteria are included in the Firmicutes phylum and more particularly in the Clostridia class, Clostridiales order, most of them belonging to the Clostridiaceae family (Whitman, 2010). These bacteria have an enzymatic cellulolytic system consisting of at least 3 different types of cellulases: exoglucanases, endoglucanases and $\beta$-glycosidases, which synergistically provide complete cellulose hydrolysis (Juturu and $\mathrm{Wu}, 2014$ ).

Zhang et al. (2015) obtained high hydrogen production yields with cellulose $(772 \mathrm{~mL})$, carboxymethylcellulose $(646 \mathrm{~mL})$ and corn stalk $(1308 \mathrm{~mL})$ using Clostridium sartagoforme, which was isolated from cow dung compost. Different bacterial cellulolytic strains have been isolated from self-fermentation of cellulosic material and used as inoculum in fermentative systems. Mazareli et al. (2019) isolated Bacillus sp. from banana residues and used this strain as inoculum for the fermentative production of hydrogen from pure and complex substrates. The authors reported hydrogen production of 36.3 and $59.6 \mathrm{~mL}$ using xylose and maltose, respectively, and when banana residues were used as substrate, hydrogen production was $106.5 \mathrm{~mL}$.

When combined, qPCR and RT-qPCR analyses are useful tools for the specific detection and quantification and analysis of transcriptional cellulolytic activity (Dollhofer et al., 2016). These analyses have been widely applied in both environmental samples (Béra-maillet et al., 2009; Singh et al., 2014; Dollhofer et al., 2016) and in fermentative reactors (Lu and Lee, 2015; Salimi and Mahadevan, 2013) for monitoring bacterial activity (Béra-maillet et al., 2009; Lu and Lee, 2015; Salimi and Mahadevan, 2013) and cellulolytic fungi (Dollhofer et al., 2016).

Béra-maillet et al. (2009) evaluated expression of cellulolytic enzymes of the bacterium Fibrobacter succinogenes from sheep rumen microbiota by RT-qPCR analysis. The authors compared cellulase expression in sheep containing $\mathrm{F}$. succinogenes as the only cellulolytic bacterium with the complex microbiota of a conventional sheep. The level of gene transcription in the monoculture was about two logs higher than that measured in the conventional animal, since F. succinogenes in monoculture does not compete with other species for the degradation of vegetal fibers.

The qPCR analysis was used by Dollhofer et al. (2016) for the quantification of anaerobic fungi in environmental samples. According to the results of these authors, the quantification of anaerobic fungi (in number of copies $/ \mathrm{mL})$ in biogas digesters was lower $\left(1.78 \times 10^{8}\right)$ than the amount reported in rumen fluid $\left(1.69 \times 10^{10}\right)$ and in cattle feces $\left(1.88 \times 10^{9}\right.$ to $\left.6 \times 10^{9}\right)$, since it does not represent their natural habitat. Based on the RT-qPCR analyses, there was no transcriptional cellulolytic fungal activity in biogas digesters. Bacterial cellulolytic activity in biogas digesters was evaluated by Wei et al. (2015) and, contrary to fungal activity, it was shown that bacterial endoglucanases were significant in these environments.

In the present study, the cellulolytic bacterium Paraclostridium sp. CR4 was isolated from self-fermentation of sugarcane bagasse. The bacterium was used as inoculum in fermentative reactors for the hydrolysis and fermentation of cellulose and also sugarcane bagasse for hydrogen production. Quantification and expression of the cellulase family protein gene were monitored by real-time polymerase chain analysis (qPCR) and reverse transcription followed by qPCR (RT-qPCR). These analyses were applied to samples of fermentative reactors with cellulose and sugarcane bagasse as substrates and Paraclostridium sp. CR4. The building stages of specific primers were necessary for this bacterial species, as well as for the study of reference genes to normalize gene expression.

\section{Material and methods}

\subsection{Strain isolation}

Sugarcane bagasse ( $\mathrm{SCB}$ ) used as a source of autochthonous bacteria was supplied by Usina São Martinho (Pradópolis, SP, Brazil).

SCB self-fermentation assays were performed using $500 \mathrm{~mL}$ Duran ${ }^{\circledR}$ flasks with $250 \mathrm{~mL}$ autoclaved PCS medium ( $1.0 \mathrm{~g} / \mathrm{L}$ yeast extract, $5.0 \mathrm{~g} / \mathrm{L}$ peptone, $2.0 \mathrm{~g} / \mathrm{LCaCO}_{3}$, and $5.0 \mathrm{~g} / \mathrm{L} \mathrm{NaCl}$ ), and sugarcane bagasse $(7.0 \mathrm{~g} / \mathrm{L})$. The reactors were subjected to $\mathrm{N}_{2}$ atmosphere $(100 \%)$ for $15 \mathrm{~min}$, closed with butyl cap and plastic screw, and incubated at $37^{\circ} \mathrm{C}$ for 10 days.

Samples of the liquid fractions of SCB self-fermentation reactors were seeded in Petri dishes with RCM (Reinforced Clostridium Medium - Oxoid $®$ ) and $1.5 \%$ nutrient agar (Difco $®$ ). The petri dishes were incubated in GasPack Jar with Anaerobic filter (Probac $®$ ) at $37^{\circ} \mathrm{C}$ for $48 \mathrm{~h}$.

Isolated colonies were collected aseptically with platinum needle and resuspended in Hungate tubes with $7.0 \mathrm{~mL}$ of PCS medium and a strip of filter paper $(5 \times 1 \mathrm{~cm})$ as substrate. The flasks were subjected to $\mathrm{N}_{2}$ atmosphere (100\%), closed with butyl cap and plastic screw, and incubated at $37^{\circ} \mathrm{C}$ for 10 days. Cell growth of CR4 cellulolytic culture was identified by the degradation of the filter paper. The culture was then transferred to $100 \mathrm{~mL}$ Duran $\circledast$ flasks with $50 \mathrm{~mL}$ PCS culture medium and glucose as carbon source $(5 \mathrm{~g} / \mathrm{L})$. The flasks were subjected to $\mathrm{N}_{2}$ atmosphere (100\%), closed with butyl cap and plastic screw, and incubated at $37^{\circ} \mathrm{C}$.

Microscopic examinations with the CR4 isolate were performed under an Olympus BX60-FLA optical microscope using common light. The Gram staining technique was performed according to the procedure described in DSM (1991). After identification, CR4 bacterial culture samples were stored in glycerol $(50 \%)$ at $-80^{\circ} \mathrm{C}$.

\subsection{Strain ident fication and phylogenetic analysis}

Extraction of genomic DNA from CR4 isolated culture was performed by Purilink Microbiome DNA Purification Kit (Invitrogen). For amplification of the 16S rRNA gene, the primer set 27F-1492R (Lane, 1991) and GoTaq ${ }^{\circledR}$ Master Mixes (Promega) were used according to the 
manufacturer's instructions. The amplicons were sequenced by the Sanger method at the Animal Biotechnology Laboratory, Department of Zootechnics (ESALQ/USP Piracicaba). The nucleotide sequences were processed in SeqMan DNASTAR (Lasergene sequence analysis) to exclude low quality bases. Then, the sequences were compared with Genbank (https://blast.ncbi.nlm.nih.gov/Blast.cgi) for taxonomic identity. Genetic distance dendrogram was constructed by the Maximum Likelihood Method based on the Tamura-Nei model (Tamura and Nei, 1993). The percentage of replicas was calculated based on bootstrap values with 1000 replicas. The analysis was performed using MEGA7 (Kumar et al., 2016) using Bacteroides vulgatus as Outgroup.

The sequence data was deposited in NCBI Sequence Read Archive under accession number MN003025.

\subsection{Batch fermentation from glucose and cellulose}

Batch experiments with Paraclostridium sp. CR4, glucose and/or cellulose as substrates were carried out in triplicate, in $250 \mathrm{~mL}$ Duran ${ }^{\circledR}$ flasks ( $125 \mathrm{~mL}$ reaction volume and $125 \mathrm{~mL}$ headspace), autoclaved RCM modified medium (13.0 g/L yeast extract, $10.0 \mathrm{~g} / \mathrm{L}$ peptone, $5.0 \mathrm{~g} / \mathrm{LNaCl}, 3.0 \mathrm{~g} / \mathrm{L}$ sodium acetate and $0.5 \mathrm{~g} / \mathrm{L}$ cysteine), pH 6.8. A control assay with Paraclostridium sp. CR4 and autoclaved RCM modified medium without carbon source was also conducted.

To adapt the CR4 isolate in cellulose, the experiments were performed with the gradual increase of the cellulose concentration, and the organic substrate (glucose and/or cellulose) was added as described in Table 1.

CR4 was used as inoculum ( $10 \% \mathrm{v} / \mathrm{v})$ for the initial experiment with $100 \%$ glucose $(\mathrm{A})$. In successive assays, in the hydrogen production stabilization stage, cells were concentrated by centrifugation ( $8000 \mathrm{rpm} /$ $10 \mathrm{~min}, 4^{\circ} \mathrm{C}$ ) and used in subsequent experiments ( $\mathrm{A}$ to $\mathrm{B}, \mathrm{B}$ to $\mathrm{C}, \mathrm{C}$ to $\mathrm{D}$ and $\mathrm{D}$ to $\mathrm{E}$ ) in order to favor the adaptation of the isolate to the cellulose substrate. The cell suspension of experiment $E$ was concentrated by centrifuge and preserved in glycerol at $-80{ }^{\circ} \mathrm{C}$ for use as substrate in sugarcane bagasse experiments.

To monitor the experiments, analysis of hydrogen $\left(\mathrm{H}_{2}\right)$ and organic acids production (according to Rabelo et al., 2018a) and soluble sugars (according to DuBois et al., 1956 modified by Herbert et al., 1971) were carried out. Samples were taken according to the $\mathrm{H}_{2}$ production stages, that is, at the initial stage of the experiment (Initial), initial $\mathrm{H}_{2}$ production stage $\left(\mathrm{IH}_{2} \mathrm{P}\right.$ in $\left.3 \mathrm{~h}\right)$, maximum $\mathrm{H}_{2}$ production $\left(\mathrm{MRH}_{2} \mathrm{P}\right.$ in $48 \mathrm{~h}$ for $\mathrm{A}$ and $\mathrm{C}, 24 \mathrm{~h}$ for $\mathrm{B}, 78 \mathrm{~h}$ for $\mathrm{D}$ and $36 \mathrm{~h}$ for $\mathrm{E}$ ) and $\mathrm{H}_{2}$ production stabilization $\left(\mathrm{SH}_{2} \mathrm{P}\right.$ in $180 \mathrm{~h}$ for $\mathrm{A}, \mathrm{D}$ and $\mathrm{E}, 48 \mathrm{~h}$ for $\mathrm{B}$ and $156 \mathrm{~h}$ for $\left.\mathrm{C}\right)$.

\subsection{Batch fermentation assays for $\mathrm{H}_{2}$ production from sugarcane bagasse}

Sugarcane bagasse (SCB) was supplied by São Martinho sugar mill (Pradópolis, SP, Brazil).

The experiments were carried out with in natura SCB; heat pretreated SCB (autoclaved, $121^{\circ} \mathrm{C}, 1.5 \mathrm{~kg} / \mathrm{cm}^{2}$, for $15 \mathrm{~min}$ ) and hydrothermally pretreated SCB (in hydrothermal reactor, $200^{\circ} \mathrm{C}$ for $10 \mathrm{~min}$ at 16 bar, according to Soares et al., 2017).

The solid phase from the hydrothermal pretreatment was washed in running water until the complete removal of the dark color to eliminate

Table 1

Concentration ( $\mathrm{g} / \mathrm{L}$ ) and percentage (\%) of glucose and/or cellulose in experiments A, B, C, $\mathrm{D}$ and $\mathrm{E}$.

\begin{tabular}{llllll}
\hline \multirow{2}{*}{ Experiments } & Glucose & & & Celullose & \\
\cline { 2 - 3 } \cline { 5 - 6 } & $\mathrm{g} / \mathrm{L}$ & $\%$ & & $\mathrm{~g} / \mathrm{L}$ & $\%$ \\
\hline $\mathrm{A}$ & 5 & 100 & & Without & Without \\
$\mathrm{B}$ & 3.75 & 75 & & 1.25 & 25 \\
$\mathrm{C}$ & 2.5 & 50 & & 2.5 & 50 \\
$\mathrm{D}$ & 1.25 & 25 & & 3.75 & 75 \\
$\mathrm{E}$ & Without & Without & & 5 & 100 \\
\hline
\end{tabular}

inhibitory compounds (furfural and hydroxymethylfurfural) that may be present after the pretreatment.

The in natura and pretreated substrates were dried and prepared according to NREL procedure (Hames et al., 2008) and were subsequently used in the $\mathrm{H}_{2}$ production assays in batch reactors.

Assays were performed in batch reactors (triplicates) using $250 \mathrm{~mL}$ Duran ${ }^{8}$ flasks. $125 \mathrm{ml}$ of modified RCM culture medium (pH 6.8), SCB $(5.0 \mathrm{~g} / \mathrm{L})$ was added as the sole carbon source and cellulose-grown Paraclostridium sp. CR4 culture (experiment E) as inoculum (10\% v/v). After inoculation, the reactors were subjected to $\mathrm{N}_{2}$ atmosphere (100\%) for $15 \mathrm{~min}$ for headspace gas exchange. After $15 \mathrm{~min}$, the reactors were closed with a butyl cap and plastic screw and incubated at $37^{\circ} \mathrm{C}$ until the stabilization of $\mathrm{H}_{2}$ production.

Analyses of $\mathrm{H}_{2}$ were performed using a gas chromatograph (Rabelo et al., 2018a). Organic acids, furfural and hydroxymethylfurfural were quantified by a high performance liquid chromatograph (Rabelo et al., 2018a). Soluble sugars were determined by the colorimetric method (DuBois et al., 1956, modified by Herbert et al., 1971). The samples were taken according to the $\mathrm{H}_{2}$ production phases, that is, at the initial stage of the experiment (Initial), initial $\mathrm{H}_{2}$ production stage $\left(\mathrm{IH}_{2} \mathrm{P}\right.$ in $3 \mathrm{~h}$ ), maximum $\mathrm{H}_{2}$ production rate stage $\left(\mathrm{MRH}_{2} \mathrm{P}\right.$ in $\left.12 \mathrm{~h}\right)$ and $\mathrm{H}_{2}$ production stabilization stage $\left(\mathrm{SH}_{2} \mathrm{P}\right.$ in $\left.46 \mathrm{~h}\right)$.

\subsection{Kinetic parameters}

Cumulative $\mathrm{H}_{2}$ production data were adjusted using the Gompertz equation, modified by Zwietering et al. (1990). This model has been used to describe the progress of cumulative $\mathrm{H}_{2}$ production in batch experiments (Lay, 2001; Guo et al., 2010; Rabelo et al., 2017; Soares et al., 2017).

Based on the modified Gompertz equation (Eq. (1)), it was possible to estimate the maximum potential $\mathrm{H}_{2}$ production $(\mathrm{P})$, maximum $\mathrm{H}_{2}$ production rate $(\mathrm{Rm})$ and initial $\mathrm{H}_{2}$ production stage $(\lambda)$.

$\mathrm{H} \quad \mathrm{P} \cdot \exp \{-\exp$ \}

$\mathrm{H}$ is the cumulative $\mathrm{H}_{2}$ production $(\mathrm{mL}), \mathrm{t}$ is the operation time (hours) and e is 2.71.

The generation time was calculated according to Eq. (2) (Mazareli et al., 2019).

$\ln N-\ln \mathrm{N}_{0} \quad(\quad) \cdot \Delta \mathrm{t}$

where, $\mathrm{N}=$ maximum cell number (copy numbers); $\mathrm{N}_{0}=$ initial cell number (copy numbers); $\Delta \mathrm{t}=$ period of $\mathrm{MRH}_{2} \mathrm{P}(\mathrm{h})$ and $\mathrm{Tg}=$ generation time (h).

The consumption of soluble carbohydrates (\%) was calculated using Eq. (3) (Rabelo et al., 2018b):

\% Sugar consumed $\frac{\mathrm{Ci}-\mathrm{Cf}}{\mathrm{Ci}} \times 100$

where $\mathrm{Ci}$ is the concentration of soluble carbohydrates at the initial stage and $\mathrm{Cf}$ is the soluble carbohydrates concentrations in the $\mathrm{H}_{2}$ production stabilization stage.

\subsection{Quantification and gene expression analysis by q-PCR and RT-qPCR}

2.6.1. Collection, storage and extraction of genetic material samples

Samples for the extraction of genetic material were collected from cellulose fermentative reactors as substrate (experiment E), according to the $\mathrm{H}_{2}$ production stages. Samples were collected at the initial stage of the experiment (Initial), initial $\mathrm{H}_{2}$ production stage $\left(\mathrm{IH}_{2} \mathrm{P}\right.$ in $\left.3 \mathrm{~h}\right), \mathrm{H}_{2}$ production maximum rate stage $\left(\mathrm{MRH}_{2} \mathrm{P}\right.$ in 21 and $\left.48 \mathrm{~h}\right)$ and $\mathrm{H}_{2}$ production stabilization stage $\left(\mathrm{SH}_{2} \mathrm{P}\right.$ in $\left.180 \mathrm{~h}\right)$. 
Samples of the hydrothermally pretreated SCB fermentation reactors were also collected. Samples were collected at the initial stage of the experiment (Initial), initial $\mathrm{H}_{2}$ production stage $\left(\mathrm{IH}_{2} \mathrm{P}\right.$ in $\left.3 \mathrm{~h}\right), \mathrm{H}_{2}$ production maximum rate stage $\left(\mathrm{MRH}_{2} \mathrm{P}\right.$ in 6 and $\left.12 \mathrm{~h}\right)$ and $\mathrm{H}_{2}$ production stabilization stage $\left(\mathrm{SH}_{2} \mathrm{P}\right.$ in $\left.46 \mathrm{~h}\right)$.

DNA extraction samples $(2.0 \mathrm{~mL})$ were collected with syringes directly from the reactors and stored in $2.0 \mathrm{~mL}$ microtubes at $-20^{\circ} \mathrm{C}$. Genomic DNA extraction was performed using the Purilink Microbiome DNA Purification Kit (Invitrogen), according to the manufacturer's protocol.

RNA extraction samples $(0.5 \mathrm{~mL})$ were collected with syringes directly from the reactors and stored in $2.0 \mathrm{~mL}$ microtubes containing $1.0 \mathrm{~mL}$ of RNA Protect bacteria reagent (Qiagen $®$ ), according to the protocol described by the manufacturer, and stored at $-20^{\circ} \mathrm{C}$. RNA extraction was preceded by a bacterial lysis stage that was performed using Proteinase $\mathrm{K}$ and Lisozime according to the Qiagen ${ }^{\circledR}$ RNA extraction protocol. RNA extraction and purification were performed with RNeasy Mini Kit (Qiagen ${ }^{\circledR}$ ) according to the manufacturer's protocol.

\subsubsection{DNAs treatment and reverse transcription}

RNA samples were subjected to DNase treatment with DNase RQ1 rnase-free enzyme (Promega ${ }^{\circledR}$ ) and the procedure was performed according to the manufacturer's protocol. Complementary DNA strand (cDNA) was synthesized from the RNA sample. The enzyme GoScript Reverse Transcription System (Promega ${ }^{\circledR}$ ) and Random primers (IDT ${ }^{\circledR}$ ) were used according to the manufacturer's protocol.

\subsubsection{Design of spec fic primers}

The oligonucleotide pairs for the cellulase (Cel) gene were designed according to cellulase family protein gene sequences from Paraclostridium sp. described in Genbank (https://www.ncbi.nlm.nih. gov/nuccore/AVNC01000015.1) and using the Primer3 computer program (http://bioinfo.ut.ee/primer3/).

Three reference genes (GyrB, Pfo and RecA) for Paraclostridium sp. were proposed, designed (http://bioinfo.ut.ee/primer3/) according to NCBI specific sequences (https://www.ncbi.nlm.nih.gov/nuccore/ AVNC01000015.1). The stability of reference genes was analyzed with the BestKeeper tool according to Pfaffl et al. (2004).

\subsubsection{Real time quantitative PCR}

Reactions were performed on MicroAmp Optical 96-Well Reaction (Thermofisher) microplates, where $2.0 \mu \mathrm{L}$ of each DNA or cDNA sample, $7.5 \mu \mathrm{L}$ of QuantiNova SYBR ${ }^{\circledR}$ Green PCR Kit, $0.75 \mu \mathrm{L}$ of Rox Reference Dye (Invitrogen ) diluted $1: 10 \mathrm{v} / \mathrm{v}, 0.3 \mu \mathrm{L}$ of each set primer diluted to $10 \mu \mathrm{M}$ (Results and discussion Table 5) and $4.15 \mu \mathrm{L}$ of UltraPure DNase/RNase-Free Distilled Water (Invitrogen ) were added. The plates were sealed with MicroAmp Clear Adhesive Film (Thermofisher) for optical reading. Assays were performed on a 7500 Real-time PCR System ${ }^{\circledR}$ thermal cycler (Applied Biosystems ).

The thermal profile of the thermal cycler consisted of a first cycle at $95^{\circ} \mathrm{C}$ for $5 \mathrm{~min}$, followed by 40 cycles at $95^{\circ} \mathrm{C}$ for $15 \mathrm{~s}$ and $60^{\circ} \mathrm{C}$ for $30 \mathrm{~s}$. At the end of the cycles, the amplification products were dissociated between $60{ }^{\circ} \mathrm{C}$ and $95{ }^{\circ} \mathrm{C}$, with readings every $0.5^{\circ} \mathrm{C}$ for $5 \mathrm{~s}$ to evaluate the melting temperature $(\mathrm{Tm})$. All samples were tested in duplicate and, for each gene at each Real Time Quantitative Polymerase Chain Reaction (qPCR) run, a template control (NTC) was included. After amplification, the results were expressed as Quantification Cycles (Cq).

\subsubsection{Absolute quant fication}

For DNA quantification, a standard curve was constructed using synthetic DNA (GBlock ${ }^{\circledR}$ Gene fragments, IDT) with the specific sequence CTATTGTTTACTGTAGAACTATTTATGCATTTAACCAACTCCTCAACTGTA TTTATAGGTTTATCACTAAGCTCAAAATAAGCTGCAATAGATATAAAATC TACTTTCGAAAACAATTTGTTATTTAATTTTTCATTATATAATTCTTTACTTT TGAGATCCCATTTTGCAGTGTACCACCATGAAGTTTTATATGTTACAAGTCC TTTGAATCTCTTTTTCGTAAAATCTATTATGTCACATTAAAAGAGTGTTC
AAATGTTGGTAAATGTGGGGTCTGTGCAGTAGAAGTTGAAGGAAAAAAGG TTCTTTCTCTTGCATGTTTAACTAAAGTAGAAGAAGGTATGGTTGTAAGA ACTAATACTGAGGCAACACAAGAGAGAGTAAAGATGAGAGTGGCAGCTTT ACTTGACAAACATGAATTCAAATGTGGACCATGTCCTCGAAGAGAGACAT GTGAATTCTTAAAATTAGTAATC.

The GBlock ${ }^{\circledR}$ contained $500 \mathrm{ng}$ mass ( $1691 \mathrm{fmol}$ ) and was eluted in $100 \mu \mathrm{L}$ of TE solution. Serial dilutions of constant ratio of 10 were performed from this concentration. Diluted aliquots from $10^{-3}$ to $10^{-9}$ were subjected to the same qPCR quantitation conditions as the DNA samples.

The Cq (quantitation cycle) values obtained from the qPCR were used to calculate and plot a linear regression line by logging the template copy number (NC) and the corresponding Cq value.

The efficiency of qPCR (E) reaction was calculated according to Eq. (4) (Pfaffl, 2001), and the mathematical conversion of $E$ to percentage according to Eq. (5).

E $10^{-1 \text { slope }}$

$\mathrm{E} \%(\quad) * 100$

In the above equations, $\mathrm{E}$ represents the efficiency, and slope is the line derived from the calibration curve. 100\% efficiency means that the target DNA is being duplicated at every cycle.

\subsubsection{Relative quantification}

The relative quantification of Cel gene expression was normalized to the Pfo gene, and calibrated according to the initial samples (zero time).

The quantification was performed according to the mathematical model proposed by Pfaffl (2001) which calculates the relative expression ratio based on qPCR efficiency and the crossing point deviation of the investigated transcripts (Eq. (6)).

Relative Expression $\frac{\mathrm{E}_{\mathrm{cel}} \Delta \mathrm{Cq}_{\text {cel }} \text { sample control }}{\mathrm{E}_{\mathrm{Pfo}} \Delta \mathrm{Cq}_{\mathrm{Pfo}} \text { sample control }}$

where, $\mathrm{E}_{\text {cel }}$ is the efficiency of the qPCR reaction with the Cel gene, $\mathrm{E}_{\mathrm{Pfo}}$ is the efficiency of the qPCR reaction with the Pfo gene, and control is the initial sample (zero time).

Pfaffl's (2001) model was chosen because it considers the efficiency values of qPCR (E); since, for environmental samples and bacterial strains, the E value differs significantly (Brankatschk et al., 2012).

\section{Results and discussion}

\subsection{CR4 ident fication and characterization}

The isolated strain CR4 of SCB auto-fermentation grew on agar surface and formed circular, smooth and cream color colony. According to microscopic examination, the strain was rod-shaped, gram-positive, $1.2 \times 3.3 \mu \mathrm{m}$, and forming terminal endospores. The occurrences of cells were single, in pairs or in chains (Fig. A1, Appendices document).

The nucleotide sequence of the isolated strain CR4 was similar (100\%) to Paraclostridium genus. Fig. 1 shows the genetic distance dendrogram, the bootstrap values are shown at the nodes (\%) and the scale bar indicates the phylogenetic distance (0.050).

Paraclostridium are obligate anaerobes can utilize D-Mannitol, cellobiose, cellulose, starch, D-mannose, D-sorbitol, D-mannitol, fumarate and benzoat for cell growth (Sasi Jyothsna et al., 2016). Paraclostridium sp. have already been identified from rat feces (Kutsuna et al., 2018) and in fermentative reactors inoculated with anaerobic digester sludge and glucose or gram as substrates for $\mathrm{H}_{2}$ production (Hwang et al., 2018; Yang and Wang, 2018; Yang et al., 2019) have been reported to be efficient $\mathrm{H}_{2}$ producers (Yang et al., 2019). 


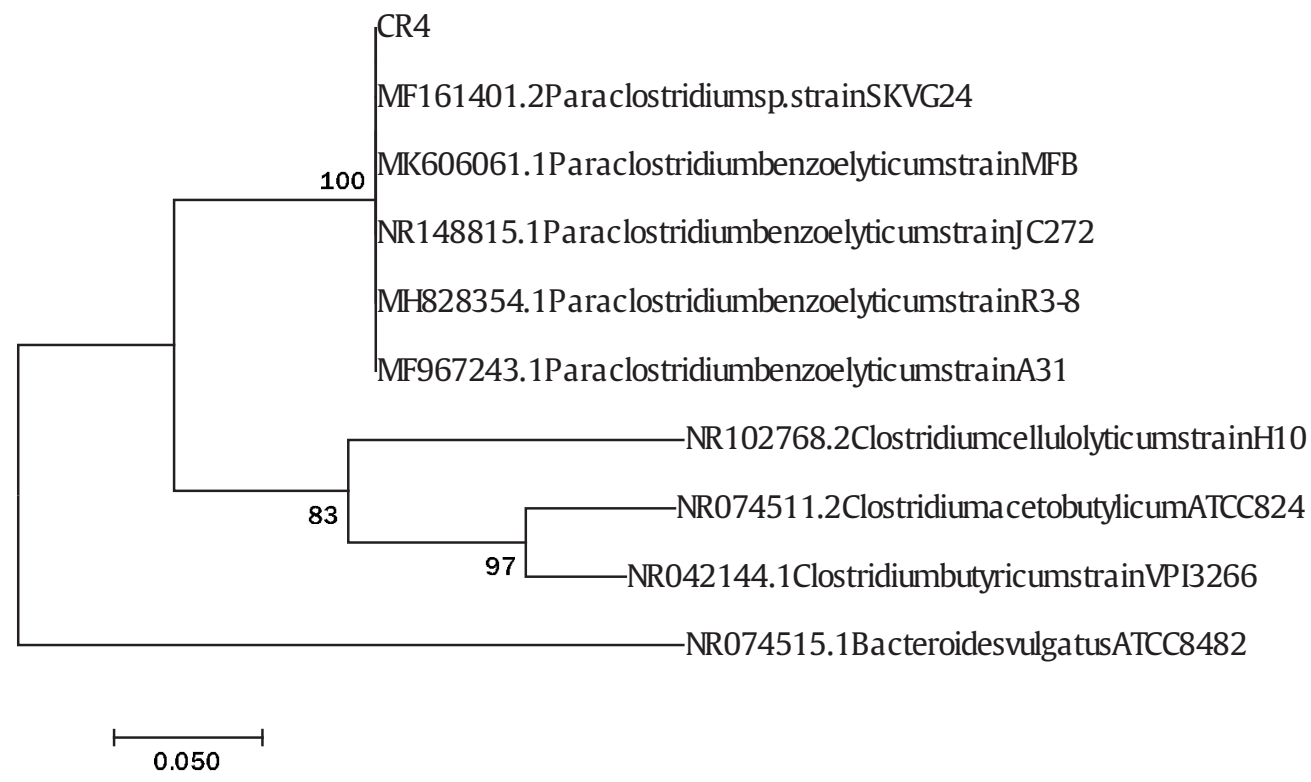

Fig. 1. Genetic distance dendrogram of the isolated strain CR4. Out-group: Bacteroides vulgatus.

Paraclostridium sp. CR4 was isolated from self-fermentation sugarcane bagasse, and this bacterium may have contributed to the degradation of SCB, as Sasi Jyothsna et al. (2016) verified cellulolytic activity of this bacterium isolated from marine sediments.

This strain was grown on cellulose $(5.0 \mathrm{~g} / \mathrm{L})$ and hydrothermally pretreated SCB $(5.0 \mathrm{~g} / \mathrm{L})$ at $37{ }^{\circ} \mathrm{C}$, and the generation time (Tg) calculated according to the copy number of the Cel gene (NC) was $4.6 \mathrm{~h}$ and $5.1 \mathrm{~h}$ for the respective substrates.

Wang et al. (2008) analyzed sucrose fermentation by Clostridium butyricum and calculated the $\mathrm{Tg}$ of $4.5 \mathrm{~h}$ from the hydA gene copy number. Braga et al. (2019) studied the cellobiose fermentation by C. cellulolyticum and calculated the tg of $4.3 \mathrm{~h}$, according to the optical density of the bacterial suspension at $600 \mathrm{~nm}$. The lowest tg values reported by these authors were probably due to the less complex substrates than cellulose and SCB.

3.2. Effect of organic substrates on hydrogen and organic acids production by Paraclostridium sp. CR4

The gradual adaptation of the inoculum to the glucose for cellulose substrate was accomplished by increasing the cellulose proportion to
$100 \%$ in order to stimulate cellulase production and, consequently, cellulose degradation. $\mathrm{H}_{2}$ production experiments were performed by Paraclostridium sp. CR4 with $100 \%$ glucose ( $5 \mathrm{~g} / \mathrm{L}$ ) (A), $75 \%$ glucose $(3.75 \mathrm{~g} / \mathrm{L})$ and $25 \%$ cellulose $(1.25 \mathrm{~g} / \mathrm{L})(\mathrm{B}), 50 \%$ glucose $(2.5 \mathrm{~g} / \mathrm{L})$ and $50 \%$ cellulose $(2.5 \mathrm{~g} / \mathrm{L})(\mathrm{C}), 25 \%$ glucose $(1.25 \mathrm{~g} / \mathrm{L})$ and $75 \%$ cellulose $(3.75 \mathrm{~g} / \mathrm{L})(\mathrm{D})$ and finally $100 \%$ cellulose ( $5 \mathrm{~g} / \mathrm{L})(\mathrm{E})$, Fig. 2.

$\mathrm{H}_{2}$ potential production ( $\mathrm{P}$ ) values differed in relation to the substrate, which were higher in the experiments with higher percentage of glucose (A and B), $162.4 \pm 5.8 \mathrm{~mL}$ and $115.8 \pm 7.6 \mathrm{~mL}$, respectively. In experiments $\mathrm{C}, \mathrm{D}$ and $\mathrm{E}, \mathrm{P}$ was $97.9 \pm 0 \mathrm{~mL}, 64.2 \pm 14.8 \mathrm{~mL}, 78.4 \pm$ $3.6 \mathrm{~mL}$, respectively.

In a control assay, without carbon source, just $7.9 \pm 0.6 \mathrm{~mL}$ of $\mathrm{H}_{2}$ were produced, since Paraclostridium sp. CR4 not only grew in amino acids source present in RCM medium.

Glucose was the preferred carbon source over cellulose for Paraclostridium sp. CR4, since the highest $\mathrm{H}_{2}$ production was in experiment A (162.4 $\pm 5.8 \mathrm{~mL})$. Glucose has been the most commonly used carbon source for determining $\mathrm{H}_{2}$ production potential either with mixed (Temudo et al., 2007; Mu et al., 2009; Masset et al., 2012) or pure cultures (Pan et al., 2008; Ren et al., 2008; Cai et al., 2010) and, as in the present study, it is the preferred carbon source when compared

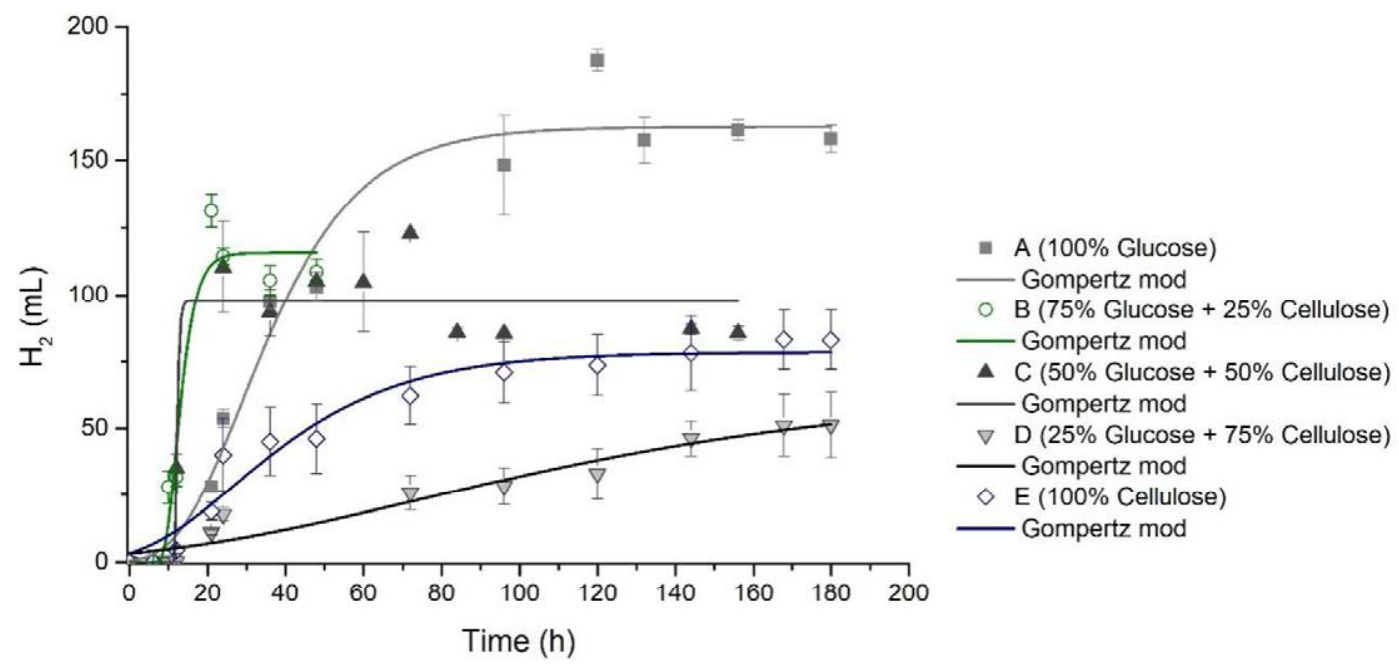

Fig. 2. $\mathrm{H}_{2}$ production by Paraclostridium sp. CR4 in experiments $\mathrm{A}, \mathrm{B}, \mathrm{C}, \mathrm{D}$ and $\mathrm{E}$. 
Table 2

Hydrogen production from cellulose as substrate.

\begin{tabular}{llll}
\hline Inoculum & $\begin{array}{l}\text { Cellulose } \\
(\mathrm{g} / \mathrm{L})\end{array}$ & $\begin{array}{l}\mathrm{H}_{2} \\
\text { production } \\
(\mathrm{mL})\end{array}$ & Reference \\
\hline C. cellulolyticum & 5.0 & 91.4 & Ren et al. (2007) \\
C. cellobuioparum & & 35.4 & \\
C. celerecrescens & & 44.6 & \\
C. populeti & & 58.7 & \\
C. phytofermentans & 2.0 & 31.8 & Ramachandran et al. (2008) \\
C. termitidis & 4.7 & Geng et al. (2010) \\
C. thermopalmarium and & 4.5 & 41.3 & \\
$\quad$ C. thermocellum & & & Present study \\
C. thermocellum & & 5.3 & \\
Paraclostridium sp. CR4 & 5.0 & 78.4 & \\
\hline
\end{tabular}

to other carbon sources for bacterial fermentation (Prakasham et al. 2009; Díaz and Willis, 2019).

Based on the increase in cellulose concentration in experiments $B$, $\mathrm{C}$ and $\mathrm{D}$, there was a gradual decrease in $\mathrm{H}_{2}$ production of $115.8 \pm$ 7.6 $\mathrm{mL}(\mathrm{B}), 97.9 \mathrm{~mL}(\mathrm{C})$ and $64.2 \pm 14.8 \mathrm{~mL}(\mathrm{D})$, respectively. Quemeneur et al. (2011) observed $\mathrm{H}_{2}$ production with glucose and cellobiose of $1120 \mathrm{~mL}$ and $1000 \mathrm{~mL}$, respectively, in batch reactors with mixed culture as inoculum, and concluded that the increase in the substrate carbon chain had a significant effect on $\mathrm{H}_{2}$ decrease. Braga et al. (2019) also evaluated $\mathrm{H}_{2}$ production with different substrates, cellobiose and pretreated SCB, from C. cellulolyticum. Higher $\mathrm{H}_{2}$ production (23.4 mL) was obtained with cellobiose compared to SCB $(11.9 \mathrm{~mL})$, because cellobiose is a more readily biodegradable substrate. Decreased $\mathrm{H}_{2}$ production with increasing cellulose concentration with Paraclostridium sp. CR4 may also have been due to the increased carbon chain and the need for previous substrate hydrolysis for subsequent fermentation.

In assay $\mathrm{E}$, with $100 \%$ cellulose, $\mathrm{H}_{2}$ production $(78.4 \pm 3.6 \mathrm{~mL}$ ) was $22.1 \%$ higher than that observed in assay D with $25 \%$ glucose and $75 \%$ cellulose $(64.2 \pm 14.8 \mathrm{~mL})$. According to Petitdemange et al. (1992), cellulase production in cellulolytic bacteria, such as Paraclostridium, is subject to low energy state-induced gene regulation within the cell, which occurs during balanced growth. In contrast, in easily metabolizable substrates such as glucose, the cellulase production is suppressed. Thus, the results obtained under condition $\mathrm{E}$ may have been due to the higher activity of the cellulolytic enzymes of Paraclostridium sp. CR4 in relation to condition D.

$\mathrm{H}_{2}$ production ( $78.4 \mathrm{~mL}$ ) by Paraclostridium sp. CR4 with $5.0 \mathrm{~g} / \mathrm{L}$ cellulose at $37^{\circ} \mathrm{C}$ was higher than that reported by Geng et al. (2010), who obtained $41.3 \mathrm{~mL}$ of $\mathrm{H}_{2}$ using co-culture of $\mathrm{C}$. thermocellum and C. thermopalmarium in batch reactors with $4.5 \mathrm{~g} / \mathrm{L}$ cellulose at $55{ }^{\circ} \mathrm{C}$. The production of $\mathrm{H}_{2}$ with Paraclostridium sp. CR4 was also higher compared to the pure cultures C. cellobuioparum $(35.4 \mathrm{~mL})$, C. celerecrescens (44.6 mL), C. populeti $(58.7 \mathrm{~mL})$ and C. phytofermentans $(31.8 \mathrm{~mL})$ in batch reactors with $5.0 \mathrm{~g} / \mathrm{L}$ of cellulose at $30{ }^{\circ} \mathrm{C}$ (Ren et al., 2007); and also compared to C. termitidis $(4.7 \mathrm{~mL}$ ) in batch reactors with $2.0 \mathrm{~g} / \mathrm{L}$ cellulose at $37^{\circ} \mathrm{C}$ (Ramachandran et al., 2008) (Table 2).

Paraclostridium belongs to the Clostridiaceae family, with the same physiological and morphological characteristics as Clostridium, such as fermentative $\mathrm{H}_{2}$ production from organic substrates. However, with the exception of cellular fatty acid constitution, in which Paraclostridium has more $C_{16: 0}$ (16-carbon fatty acid in saturated bonds), differentiating it from Clostridium (Sasi Jyothsna et al., 2016).

In all experiments (A E) with Paraclostridium CR4, the main organic acids observed were acetic and butyric (Fig. 3 ). One of the main physiological characteristics of bacteria belonging to the Clostridiaceae family (Rainey, 2009) refers to the production of these organic acids as observed for Paraclostridium sp. CR4. Acetic acid (2.9 g/L) and butyric acid $(2.8 \mathrm{~g} / \mathrm{L})$ were produced more in glucose and cellulose, respectively.

The other acids produced (lactic, citric, formic, isovaleric, valeric and caproic acids), in lower concentrations, are available in Fig. B1 (Appendix document).

In experiments with higher glucose percentage (A, B and C), acetic and butyric acids were observed mainly in the initial $\mathrm{H}_{2}$ production $\left(\mathrm{IH}_{2} \mathrm{P}\right)$ stage, and maximum $\mathrm{H}_{2}$ production rate stage $\left(\mathrm{MRH}_{2} \mathrm{P}\right)$. In experiment $\mathrm{A}$ ( $100 \%$ glucose), acetic and butyric acids were observed in higher concentration in the $\mathrm{IH}_{2} \mathrm{P}$ stage ( 2.9 and $1.3 \mathrm{~g} / \mathrm{L}$, respectively), while in experiments $\mathrm{B}$ ( $75 \%$ glucose and $25 \%$ cellulose) and C ( $50 \%$ glucose and $50 \%$ cellulose), mainly in the $\mathrm{MRH}_{2}$ stage ( 2.8 and $1.5 \mathrm{~g} / \mathrm{L}$ in $\mathrm{B}$ and 2.5 and 1.5 in C, respectively).

In contrast, in experiments $\mathrm{D}$ ( $25 \%$ glucose and $75 \%$ cellulose) and $\mathrm{E}$ (100\% cellulose) with higher percentage of cellulose, acetic and butyric

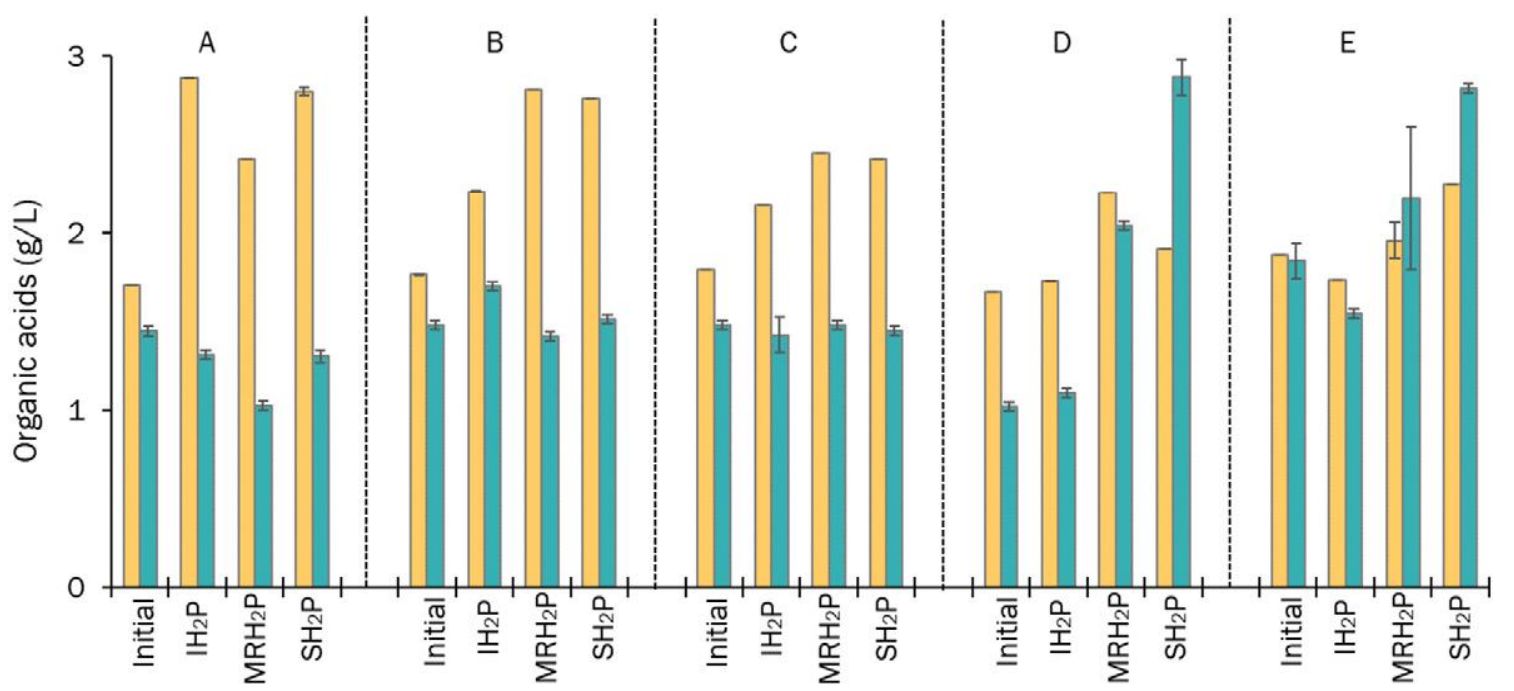

Stages of $\mathrm{H}_{2}$ production 


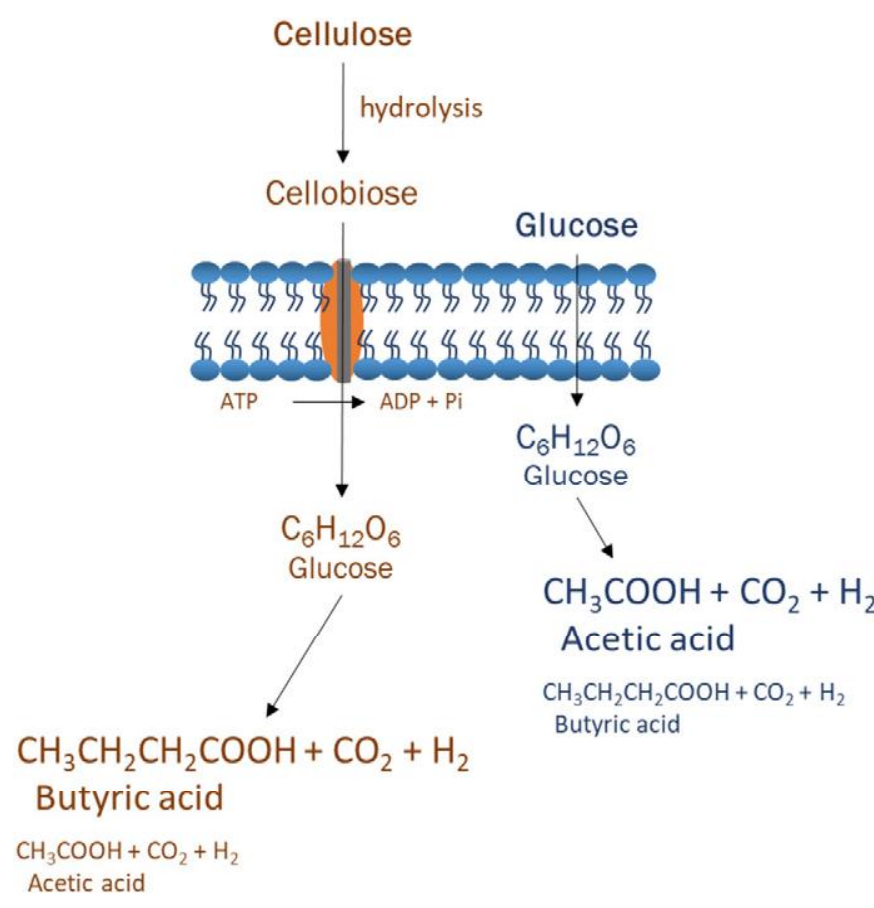

Fig. 4. Production of the main organic acids from glucose and cellulose by Paraclostridium sp. CR4.

acids were observed during the $\mathrm{H}_{2}$ production stabilization stage $\left(\mathrm{SH}_{2} \mathrm{P}\right)$; that is, 1.9 and $2.9 \mathrm{~g} / \mathrm{L}$ in $\mathrm{D}$ and 2.3 and $2.8 \mathrm{~g} / \mathrm{L}$ in E, respectively.

The effect of carbon source (glucose/cellulose) on the organic acids production period may have been due to bacterial growth in the respective substrates. According to Giallo et al. (1985), the growth of cellulolytic bacteria C. cellulolyticum in cellulose was lower compared to growth in glucose, with generation time of 24 and $10 \mathrm{~h}$, respectively, due to the hydrolysis stage of cellulose in soluble sugars.

Thus, the formation of organic acids in experiments $\mathrm{D}$ and $\mathrm{E}$ was delayed (in the $\mathrm{SH}_{2} \mathrm{P}$ stage) because of the slow growth of Paraclostridium $\mathrm{sp}$. CR4 in cellulose, due to the substrate hydrolysis stage, when compared to the formation of acids in experiments $\mathrm{A}, \mathrm{B}$ and $\mathrm{C}$, with glucose as the main substrate (in the $\mathrm{IH}_{2} \mathrm{P}$ and $\mathrm{MRH}_{2} \mathrm{P}$ stages).
Table 3

Distribution of soluble carbon content of fermentative reactors

\begin{tabular}{llclc}
\hline Experiment & $\begin{array}{l}\text { Stage of } \mathrm{H}_{2} \\
\text { production }\end{array}$ & $\begin{array}{l}\text { Organic } \\
\text { acids } \\
(\mathrm{g} / \mathrm{L})\end{array}$ & $\begin{array}{l}\text { Soluble } \\
\text { sugars } \\
(\mathrm{g} / \mathrm{L})\end{array}$ & $\begin{array}{l}\text { Total COD } \\
\text { theoretical } \\
(\mathrm{g} / \mathrm{L})\end{array}$ \\
\hline A (100\% glucose) & Initial & 7.3 & 7.7 & 15.0 \\
& $\mathrm{SH}_{2} \mathrm{P}$ & 9.4 & 1.9 & 11.3 \\
B (75\% glucose and 25\% & $\mathrm{Initial}^{2}$ & 7.0 & 3.6 & 10.6 \\
cellulose) & $\mathrm{SH}_{2} \mathrm{P}$ & 7.0 & 2.2 & 9.2 \\
C (50\% glucose and 50\% & $\mathrm{Initial}_{2}$ & 8.1 & 2.7 & 10.8 \\
cellulose) & $\mathrm{SH}_{2} \mathrm{P}$ & 8.8 & 1.5 & 10.3 \\
D (25\% glucose and 75\% & $\mathrm{Initial}^{2}$ & 7.5 & 1.2 & 8.7 \\
cellulose) & $\mathrm{SH}_{2} \mathrm{P}$ & 10.7 & 0.7 & 11.4 \\
E (100\% cellulose) & $\mathrm{Initial}^{2}$ & 9.4 & 1.0 & 10.4 \\
& $\mathrm{SH}_{2} \mathrm{P}$ & 10.3 & 1.2 & 11.5 \\
\hline
\end{tabular}

The main organic acid formed during the experiments also differed between the experiments with glucose (A, B and C) and cellulose (D and $\mathrm{E}$ ). In A ( $100 \%$ glucose), B (75\% glucose and $25 \%$ cellulose) and C ( $50 \%$ glucose and $50 \%$ cellulose), there was a higher production of acetic acid $(2.9,2.8$ and $2.8 \mathrm{~g} / \mathrm{L}$, respectively), while in $\mathrm{D}(25 \%$ glucose and $75 \%$ cellulose) and $\mathrm{E}$ ( $100 \%$ cellulose) there was a predominance of butyric acid ( 2.9 and $2.8 \mathrm{~g} / \mathrm{L}$, respectively), suggesting that bioconversion of glucose occurred from the acetic acid route, while cellulose bioconversion was from the butyric acid route.

According to Prakasham et al. (2009) and Gupta et al. (2014), the substrate type can regulate the formation of the final product. Gupta et al. (2014) evaluated $\mathrm{H}_{2}$ production from different proportions of glucose, starch and cellulose with mixed inoculum in batch reactors, and found that acetic and butyric acids were the predominant products in the fermentation of glucose and starch, while propionic acid was obtained from cellulose. Quemeneur et al. (2011) also evaluated the production of $\mathrm{H}_{2}$ by mixed culture in batch reactors from glucose, fructose, maltose and cellobiose. In this case, acetic and butyric acids were predominant in the fermentation of monosaccharides (glucose and fructose) and sucrose, while caproic and lactic acids were produced from cellobiose, maltose and maltotriose.

As in the above studies, the metabolic route of Paraclostridium sp. CR4 was altered due to the added substrate chain length, changing the fermentation products. With simple substrates such as glucose, the main product was acetic acid, formed in the first hours of fermentation $\left(\mathrm{IH}_{2} \mathrm{P}, 3 \mathrm{~h}\right)$. From cellulose, the butyric acid route was favored, however with delayed organic acid production $\left(\mathrm{SH}_{2} \mathrm{P}, 180 \mathrm{~h}\right)$ (Fig. 4).

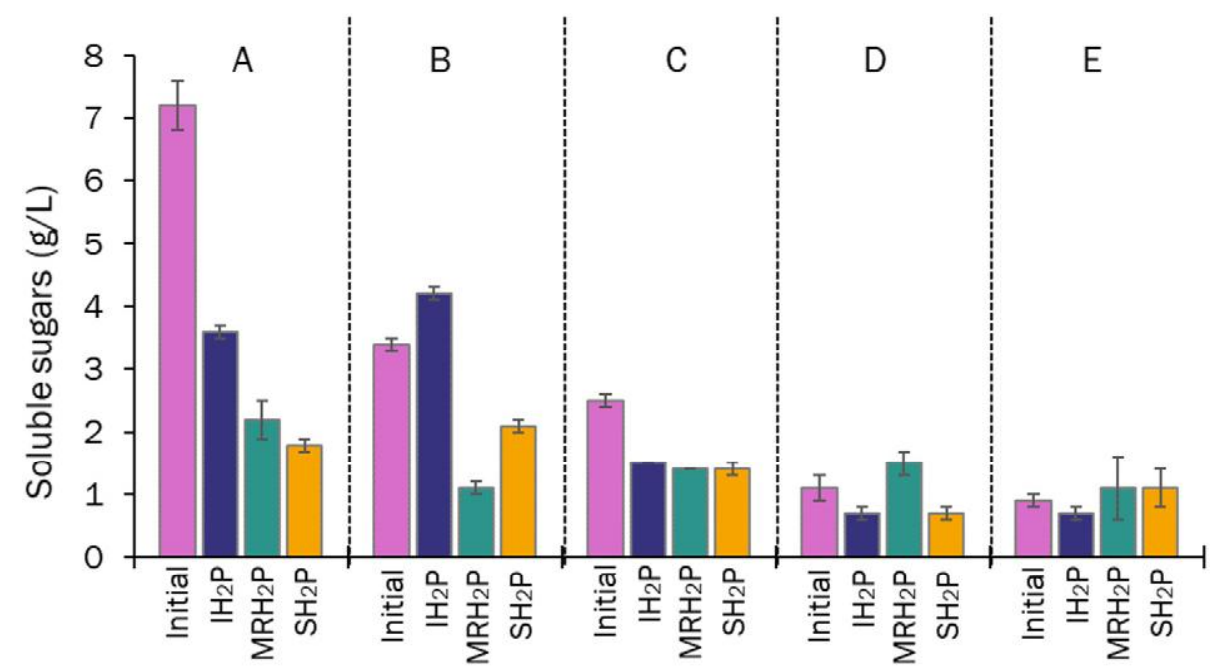

\section{Stages of $\mathrm{H}_{2}$ production}

Fig. 5. Soluble sugars in experiments A, B, C, D and E, during the $\mathrm{H}_{2}$ production stages, at the initial phase of the experiment (Initial), initial $\mathrm{H}_{2}$ production ( $\mathrm{IH}_{2} \mathrm{P}$ in $3 \mathrm{~h}$ for all experiments), maximum $\mathrm{H}_{2}$ production rate $\left(\mathrm{MRH}_{2} \mathrm{P}\right.$, in $48 \mathrm{~h}$ for $\mathrm{A}$ and $\mathrm{C}, 24 \mathrm{~h}$ for $\mathrm{B}, 78 \mathrm{~h}$ for D and $36 \mathrm{~h}$ for $\left.\mathrm{E}\right)$ and $\mathrm{H}_{2}$ production stabilization $\left(\mathrm{SH}_{2} \mathrm{P}\right.$, in $180 \mathrm{~h}$ for $\mathrm{A}$, D and E, $48 \mathrm{~h} \mathrm{for} \mathrm{B}$ and $156 \mathrm{~h}$ for $\mathrm{C}$ ). 


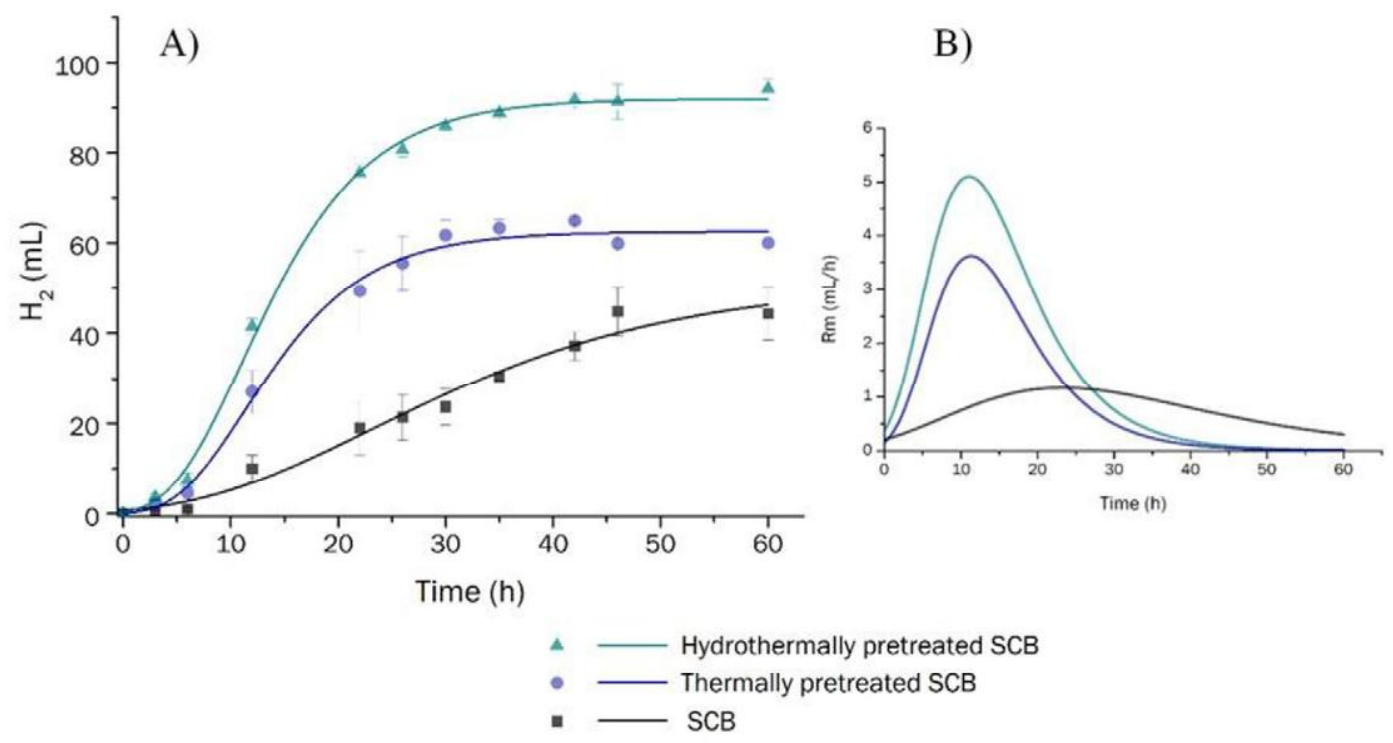

Fig. 6. A): Hydrogen production potential (P), and B): hydrogen production velocity ( $\mathrm{Rm}$ ) from SCB by Paraclostridium sp.

Total soluble sugars in these experiments (A E) were monitored during the $\mathrm{H}_{2}$ production stages and are presented in Fig. 5 .

In addition to the added substrate (glucose or cellulose), the culture medium (modified RCM medium with yeast extract, peptone, $\mathrm{NaCl}$, sodium acetate and cysteine) and inoculum also contributed to the increase of soluble sugars in the medium. At the initial stage of experiment A (100\% glucose), $7.2 \pm 0.40 \mathrm{~g} / \mathrm{L}$ of total soluble sugars was observed. Under such conditions only $5.0 \mathrm{~g} / \mathrm{L}$ glucose was added. This fact can also be evidenced in experiment $\mathrm{E}$, in which no glucose was added and yet $0.9 \pm 0.20 \mathrm{~g} / \mathrm{L}$ of total soluble sugars were obtained at the initial stage of the experiment.

In experiment $A$, only glucose showed a gradual decrease in soluble sugar concentration from $7.2 \pm 0.4 \mathrm{~g} / \mathrm{L}$ at the initial stage of the experiment (Initial) to $3.6 \pm 0.15,2.2 \pm 0.35$ and $1.8 \pm 0.05$ at the $\mathrm{H}_{2} \mathrm{P}$, $\mathrm{MRH}_{2} \mathrm{P}$ and $\mathrm{SH}_{2}$ Pstages, respectively. Thus, the carbohydrate conversion was $75.0 \%$.

In experiment $B$, with $25 \%$ of cellulose, the concentration of soluble sugars increased from $3.4 \pm 0.15 \mathrm{~g} / \mathrm{L}$ (Initial) to $4.2 \pm 0.05 \mathrm{~g} / \mathrm{L}\left(\mathrm{IH}_{2} \mathrm{P}\right)$ decreased to $1.1 \pm 0.05 \mathrm{~g} / \mathrm{L}$ and later increased to $2.1 \pm 0.15 \mathrm{~g} / \mathrm{L}$ in $\mathrm{MRH}_{2} \mathrm{P}$ and $\mathrm{SH}_{2} \mathrm{P}$, respectively.

In experiment $\mathrm{C}$, with $50 \%$ cellulose and $2.5 \pm 0.05 \mathrm{~g} / \mathrm{L}$ (Initial) of soluble sugars, only a decrease of $1.5,1.4$ and $1.4 \pm 0.15 \mathrm{~g} / \mathrm{L}$ was observed in the $\mathrm{IH}_{2} \mathrm{P}, \mathrm{MRH}_{2} \mathrm{P}$ and $\mathrm{SH}_{2} \mathrm{P}$ stages, respectively, resulting in $44.0 \%$ of carbohydrate conversion.

In experiments $\mathrm{D}$ and $\mathrm{E}$, with higher percentage of cellulose, a similar concentration of soluble sugars was observed during the $\mathrm{H}_{2}$ production stage, probably due to the simultaneous release and consumption of sugars by Paraclostridium sp. CR4. In experiment D, with $75 \%$ cellulose and $1.1 \mathrm{~g} / \mathrm{L}$ of soluble sugars (Initial), $0.7 \pm 0.15 \mathrm{~g} / \mathrm{L}\left(\mathrm{IH}_{2} \mathrm{P}\right), 1.5 \pm$ $0.20 \mathrm{~g} / \mathrm{L}\left(\mathrm{MRH}_{2} \mathrm{P}\right)$ and $0.7 \pm 0.05 \mathrm{~g} / \mathrm{L}\left(\mathrm{SH}_{2} \mathrm{P}\right)$ were observed, resulting in $36.4 \%$ of carbohydrate removal. In $\mathrm{E}$, with $100 \%$ cellulose and $0.9 \mathrm{~g} / \mathrm{L}$ of soluble sugars (Initial), $0.7 \pm 0.05 \mathrm{~g} / \mathrm{L}\left(\mathrm{IH}_{2} \mathrm{P}\right), 1.1 \pm 0.45\left(\mathrm{MRH}_{2} \mathrm{P}\right)$ and $1.1 \pm 0.35\left(\mathrm{SH}_{2} \mathrm{P}\right)$ were observed.

Rabelo et al. (2018b) also evaluated soluble sugars in cellulose fermentation and microbial consortium reactors. The authors observed higher carbohydrate conversion in reactors with higher initial cellulose concentration, i.e., 58, 66 and $74 \%$ of carbohydrate conversion in reactors with $2.0,5.0$ and $10.0 \mathrm{~g} / \mathrm{L}$ of cellulose, respectively. At the initial stage of the experiments with 2.0, 5.0 and $10.0 \mathrm{~g} / \mathrm{L}$ of cellulose, 13.9, 22.0 and $21.2 \mathrm{mg} / \mathrm{L}$ of soluble sugars were observed, respectively. During the highest $\mathrm{H}_{2}$ production stage, the concentration of soluble sugars in the medium increased to $111.9,105.0$ and 60.5 , respectively, and in the $\mathrm{H}_{2}$ production stabilization stage, a decrease to 35.1, 27.3 and $25.4 \mathrm{mg} / \mathrm{L}$ was observed, respectively.

In the present study, the concomitant increase and decrease of soluble carbohydrates in the medium during the $\mathrm{H}_{2}$ production stages were also observed, corroborating the importance of hydrolytic activity for the fermentative production of $\mathrm{H}_{2}$.

The soluble carbon content $\left(\mathrm{g} \mathrm{COD}_{\text {theoretical }} / \mathrm{L}\right)$ of fermentative reactors at the initial stage of the experiment (Initial) and $\mathrm{H}_{2}$ production stabilization $\left(\mathrm{SH}_{2} \mathrm{P}\right)$ stage can be seen in Table 3.

In experiments $\mathrm{A}$ and $\mathrm{C}$, a reduction in soluble carbon content from the Initial stage to $\mathrm{SH}_{2} \mathrm{P}$ was observed (from 15.0 to $11.3 \mathrm{~g} / \mathrm{L}$ and 10.8 to $10.3 \mathrm{~g} / \mathrm{L}$, respectively). This result was probably due to the consumption of carbon from soluble sugars (from 7.7 to 1.9 and 2.7 to $1.5 \mathrm{~g} / \mathrm{L}$, respectively), resulting in a conversion of 75 and $44 \%$, respectively, into

Table 4

Biofuel production from pretreated lignocellulosic substrates.

\begin{tabular}{|c|c|c|c|c|}
\hline Substrate & Pre-treatment & Results & Increase in production & Reference \\
\hline Corn silage $(1.3 \mathrm{~g} / \mathrm{L})$ & Hydrothermal & $19.4 \mathrm{~g} / \mathrm{L}$ of ethanol & $61.6 \%$ & Xu et al. (2010) \\
\hline \multirow[t]{3}{*}{ Beet pulp (20 g COD/L) } & Microwave and alkaline & $111.7 \mathrm{~mL}$ of $\mathrm{H}_{2}$ & $14.3 \%$ & Ozkan et al. (2011) \\
\hline & Alkaline & $134.0 \mathrm{~mL}$ of $\mathrm{H}_{2}$ & $28.6 \%$ & \\
\hline & Thermal and alkaline & $148.5 \mathrm{~mL}$ of $\mathrm{H}_{2}$ & $35 . \%$ & \\
\hline \multirow[t]{2}{*}{$\mathrm{SCB}(0.5$ and $2.0 \mathrm{~g} / \mathrm{L})$} & steam and alkaline explosion & 64. $\mathrm{mL}$ of $\mathrm{H}_{2}$ with $0.5 \mathrm{~g} \mathrm{SCB} / \mathrm{L}$ & $43.1 \%$ & Ratti et al. (2015) \\
\hline & & $157.7 \mathrm{~mL}$ of $\mathrm{H}_{2}$ with $2.0 \mathrm{~g} \mathrm{SCB} / \mathrm{L}$ & $72.4 \%$ & \\
\hline $\mathrm{SCB}(2.0 \mathrm{~g} / \mathrm{L})$ & Hydrothermal & $11.4 \mathrm{~mL}$ of $\mathrm{H}_{2}$ & $15.8 \%$ & Soares et al. (2017) \\
\hline \multirow[t]{3}{*}{$\mathrm{SCB}(5.0 \mathrm{~g} / \mathrm{L})$} & Thermal & $62.5 \mathrm{~mL}$ of $\mathrm{H}_{2}$ & $17.8 \%$ & Present study \\
\hline & Hydrothermal & $92.0 \mathrm{~mL}$ of $\mathrm{H}_{2}$ & $44.1 \%$ & \\
\hline & In natura & $51.4 \mathrm{~mL}$ of $\mathrm{H}_{2}$ & & \\
\hline
\end{tabular}




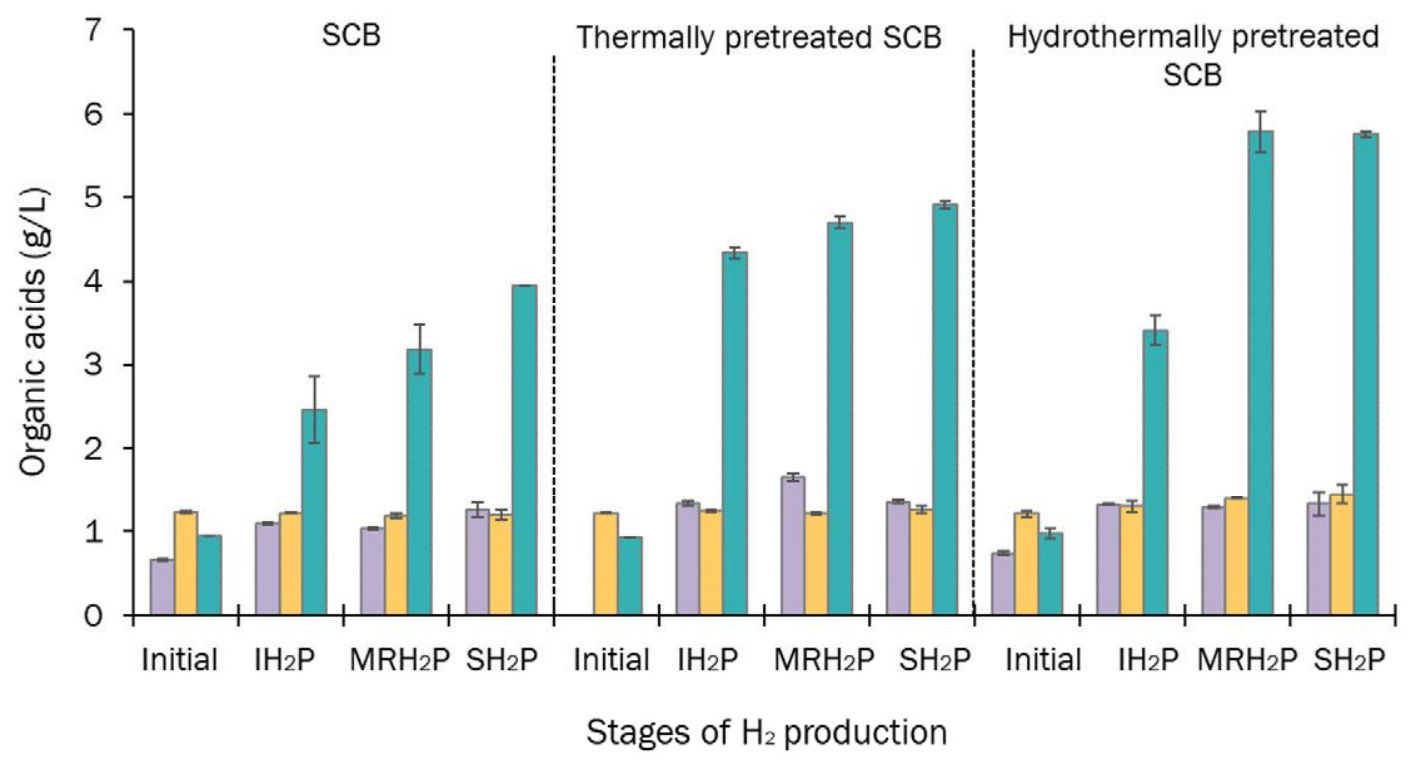

$\square$ Latic acid $\square$ Acetic acid $\quad \square$ Butyric acid

Fig. 7. Organic acids from SCB at the initial phase of the experiment (Initial, $0 \mathrm{~h}$ ), initial $\mathrm{H}_{2}$ production $\left(\mathrm{IH}_{2} \mathrm{P}, 3 \mathrm{~h}\right.$ ), maximum $\mathrm{H}_{2}$ production rate (MRH $\mathrm{P}, 12 \mathrm{~h}$ ) and $\mathrm{H}_{2}$ production stabilization $\left(\mathrm{SH}_{2} \mathrm{P}, 46 \mathrm{~h}\right)$.

organic acids (9.4 and $8.8 \mathrm{~g} / \mathrm{L}$, respectively), carbon dioxide and cell growth.

Experiment $\mathrm{B}$ also showed a reduction in the soluble carbon content from the Initial stage to $\mathrm{SH}_{2} \mathrm{P}$ (from 10.6 to $9.2 \mathrm{~g} / \mathrm{L}$ ), probably due to the conversion of substrates (cellulose and glucose) to carbon dioxide and cell growth.

In the experiments with higher amount of insoluble substrate, D and E ( 75 and $100 \%$ of cellulose, respectively), an increase in the initial soluble carbon content was observed for $\mathrm{SH}_{2} \mathrm{P}$ (from 8.7 to $11.4 \mathrm{~g} / \mathrm{L}$ and from 10.4 to $11.5 \mathrm{~g} / \mathrm{L}$, respectively), probably due to the conversion of the insoluble substrate to organic acids ( 10.7 and $10.3 \mathrm{~g} / \mathrm{L}$, respectively), and carbon dioxide and cell growth.

From these results one can infer about the hydrolytic-fermentative activity of Paraclostridium sp. CR4 in all experiments. Sasi Jyothsna et al. (2016) isolated Paraclostridium species from marine sediments, and also verified degradation of glucose and cellulose, as well as mannitol, starch, cellobiose, mannose, sorbiol, benzoate and fumarate.

\subsection{Fermentation of in natura and pretreated $\mathrm{SCB}$}

pt?> The thermal and hydrothermal pretreatments were applied to SCB in order to increase the enzymatic accessibility and digestibility of cellulose and, consequently, the glycidic fermentation for $\mathrm{H}_{2}$ production. The experiments with substrates subjected to pretreatment were compared with the control experiment (in natura $\mathrm{SCB}$ ). The in natura and pretreated SCB were used by Paraclostridium sp. CR4 for $\mathrm{H}_{2}$ production (Fig. 6).

Based on the heat-treated and hydrothermally pretreated BCA, a higher P value of $62.5 \pm 1.3$ and $92.0 \pm 1.1 \mathrm{~mL}$ of $\mathrm{H}_{2}$ was obtained,

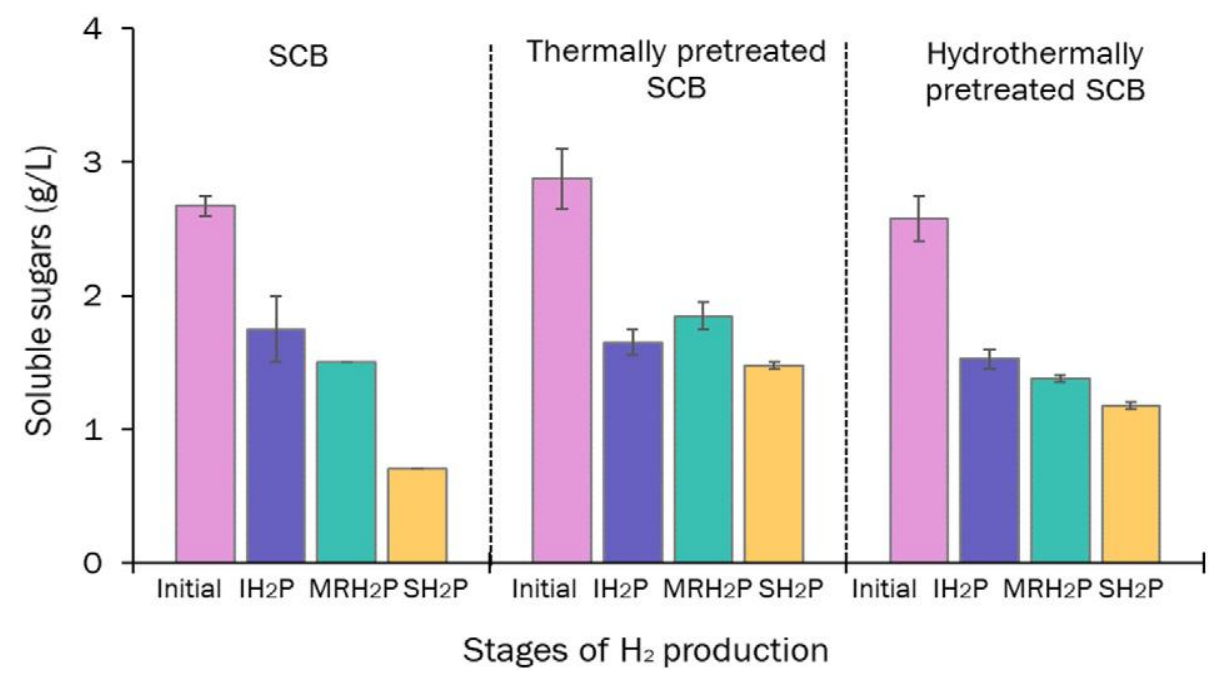

Fig. 8. Soluble sugars in batch reactors at the initial stage of the experiment (Initial), initial $\mathrm{H}_{2}$ production $\left(\mathrm{IH}_{2} \mathrm{P}\right.$ in $3 \mathrm{~h}$ ), maximum $\mathrm{H}_{2}$ production rate ( $\mathrm{MRH} \mathrm{H}_{2} \mathrm{P}$ in $12 \mathrm{~h}$ ) and $\mathrm{H}_{2}$ production stabilization $\left(\mathrm{SH}_{2} \mathrm{P}\right.$ in $\left.46 \mathrm{~h}\right)$. 
Table 5

Sequence of primers designed for Cel, GyrB, Pfo, and RecA genes.

\begin{tabular}{lll}
\hline Gene & Primer sequence & Product size (bp) \\
\hline Cel & F: TGCATTTAACCAACTCCTCAACTGT & 154 \\
GyrB & R: TGGTACACTGCAAAATGGGATCT & \\
& F: GGCTATAGTGGTGGCTCATGGA & 184 \\
Pfo & R: AGGTTGTATGCTTTGCCTCACA & \\
& F: CAGATCGTACATATCCAGGAGCTC & 180 \\
RecA & R: CAACGGCCCTGATACATTTGA & 179 \\
& F: GCTGAGATAGAAGGGGACATGGG & \\
\hline
\end{tabular}

respectively, in relation to in natura $\mathrm{SCB}(51.4 \pm 4.7 \mathrm{~mL})$ and significantly different $(\alpha=0.05)$.

Higher $\mathrm{H}_{2}$ production rate for hydrothermally pretreated SCB $(5.1 \pm$ $0.3 \mathrm{~mL} / \mathrm{h})$, compared to hydrothermally pretreated $(3.6 \pm 0.4 \mathrm{~mL} / \mathrm{h})$ and in natura (1.2 \pm 0.1$)$ was obtained and was significantly different $(\alpha=0.05)$. Under the conditions of hydrothermal pretreatment, disruption of hemicellulose and lignin and decreased crystallinity of cellulose may have occurred, resulting in greater enzymatic accessibility for fermentation.

In addition to hydrothermal pretreatment, other pretreatments have been applied to lignocellulosic biomass to increase $\mathrm{H}_{2}$ production (Ozkan et al., 2011; Ratti et al., 2015) and ethanol (Xu et al., 2010). Different pretreatment possibilities for lignocellulosic materials can be used favoring $\mathrm{H}_{2}$ production from $14.3 \%$ (Ozkan et al., 2011) to $72.4 \%$ (Ratti et al., 2015). An increase of 17.8 and $44.1 \%$ in $\mathrm{H}_{2}$ production was obtained from heat-treated and hydrothermally pretreated BCA, respectively, compared to in natura BCA (Table 4).

Butyric acid was the main organic acid formed from in natura and pre-heat treated SCB (at $121{ }^{\circ} \mathrm{C}, 1.5 \mathrm{~kg} / \mathrm{cm}^{2}$ for $15 \mathrm{~min}$ ) and hydrothermally (at $200{ }^{\circ} \mathrm{C}, 16$ bar for $10 \mathrm{~min}$ ) by Paraclostridium sp. CR4 (Fig. 7).

The highest concentration of organic acids $(8.5 \mathrm{~g} / \mathrm{L})$ occurred in the hydrothermally pretreated SCB assays, with $68.2 \%$ corresponding to butyric acid $(5.8 \mathrm{~g} / \mathrm{L}) .7 .5 \mathrm{~g} / \mathrm{L}$ and $6.4 \mathrm{~g} / \mathrm{L}$ of total organic acids were obtained from the heat-treated pretreated and in natura SCB, respectively. Braga et al. (2018) obtained $10 \mathrm{~g} / \mathrm{L}$ of total organic acids from hydrothermally pretreated SCB and consortium of cellulolytic and fermentative bacteria. Rabelo et al. (2018a) also reported organic acid production from 4.5 to $7.1 \mathrm{~g} / \mathrm{L}$ using heat pretreated SCB as substrate and consortium of fermentative cellulolytic bacteria as inoculum.

Thus, with the fermentation of SCB by Paraclostridium sp. CR4, in addition to $\mathrm{H}_{2}$, organic acids can be obtained, especially butyric acid as a product of added value.

Butyric acid is an important platform chemical, a precursor of many chemicals and materials and widely used in the chemical, food and pharmaceutical industries (Baroi et al., 2015). Butyric acid fermentative production, when compared to chemical production, has advantages such as lower production of environmental pollutants and the use of renewable resources as substrate, and this production mode is often necessary for some specific applications, such as for food and pharmaceutical industries (Luo et al., 2018).

Fermentative production of butyric acid can also be obtained from lignocellulosic substrates (Chi et al., 2018; Oh et al., 2019). Pretreated rice straw was used in batch reactors and cellulolytic bacterial consortium, as well as in batch reactors with cellulolytic bacterial consortium bioaugmented with C.tyrobutyricum. As a result, butyric acid production was increased from $5.53 \mathrm{~g} / \mathrm{L}$ with cellulolytic consortium to $18.05 \mathrm{~g} / \mathrm{L}$ with the addition of C. tyrobutyricum (Chi et al., 2018). Rabelo et al. (2018a) reported that response surface methodology and central composite design are effective statistical methodologies for the optimization of butyric acid production by bacterial consortium. The individual and mutual effects of substrate concentration (from 0.8 to $9.2 \mathrm{~g} / \mathrm{L}$ ) and $\mathrm{pH}$ (from 4.6 to 7.4) on butyric acid production from SCB were investigated in batch reactors. The authors observed an increase in butyric acid concentration from 14.6 to $33.8 \%$ of total acids produced ( 0.66 to $1.92 \mathrm{~g}$ butyric acid/L) with $2.0 \mathrm{~g} \mathrm{SCB} / \mathrm{L}$ at $\mathrm{pH} 5.0$ and $9.2 \mathrm{~g} \mathrm{SCB} / \mathrm{L}$ at $\mathrm{pH} 6.0$, respectively. In the present study, in the fermentation of SCB with Paraclostridium sp. CR4 was also able to obtain the simultaneous production of $\mathrm{H}_{2}$ and butyric acid. The highest yield of butyric acid ( $5.8 \mathrm{~g} / \mathrm{L})$, as well as $\mathrm{H}_{2}(92.0 \mathrm{~mL})$ was obtained through hydrothermally pretreated BCA followed by heat pretreated BCA ( $4.9 \mathrm{~g}$ butyric acid/L and $62.5 \mathrm{~mL} \mathrm{H}_{2}$ ) and in natura BCA (4.0 g butyric acid/L and $51.4 \mathrm{~mL}$ $\mathrm{H}_{2}$ ) at $\mathrm{pH} 6.8$.

The concentration of soluble sugars in batch reactors with in natura, heat pretreated and hydrothermally pretreated SCB were also evaluated during the $\mathrm{H}_{2}$ production stages (Fig. 8). The concentration of soluble sugars at the initial stage of the experiment was similar under the
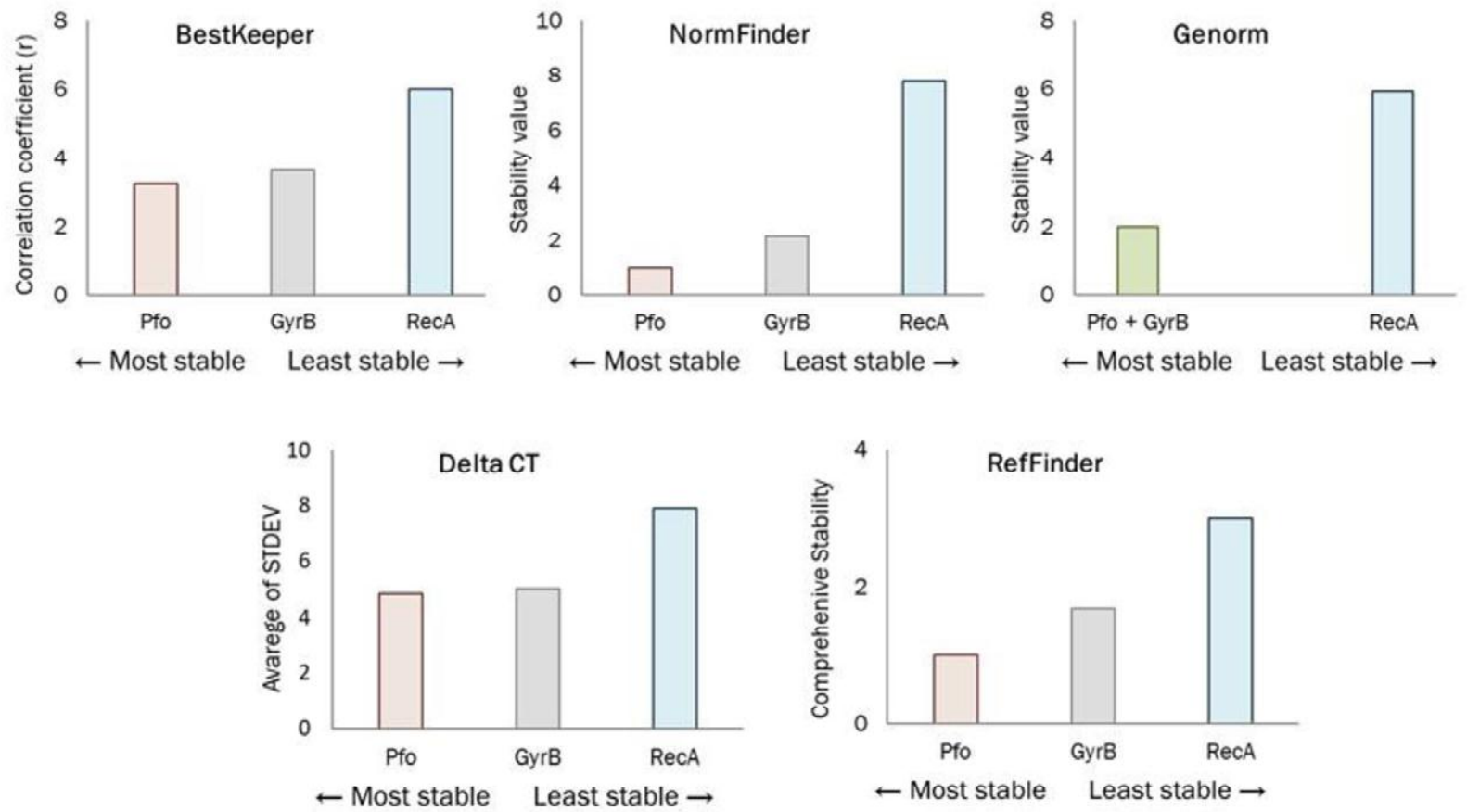

Fig. 9. Stability of reference genes according to DeltaCT, BestKeeper, NormFinder, Genorm and RefFinder. 
three conditions $(2.7,2.9$ and $2.6 \mathrm{~g} / \mathrm{L}$ with in natura SCB, heat pretreated SCB and hydrothermally pretreated SCB, respectively). Lower concentrations of soluble sugars were observed during the $\mathrm{H}_{2}$ production stages, resulting in a conversion of $73.8,48.7$ and $54.4 \%$ in the experiments with in natura, heat pretreated and hydrothermally pretreated $\mathrm{SCB}$, respectively.

In the experiment with hydrothermally pretreated $\mathrm{SCB}$, the conversion of sugars (54.4\%) was lower when compared to the in natura SCB (73.8\%) and, even so, in this experimental condition the highest $\mathrm{H}_{2}$ production $\left(92.0 \mathrm{~mL}\right.$ ) was obtained. Probably, the higher $\mathrm{H}_{2}$ production observed with hydrothermally pretreated SCB was due to the increase in available surface area of the substrate because of the hydrothermal pretreatment, which favored substrate hydrolysis in soluble sugars available for fermentation in $\mathrm{H}_{2}$ and organic acids.

3.4. Primers to target-gene and reference gene candidates for Paraclostridium

In the experiment with cellulose (E) and hydrothermally pretreated $\mathrm{SCB}$, the quantification of the celullase family protein gene (Cel) by qPCR was evaluated, and also for the quantification of Cel gene expression by RT-qPCR.

Primers for the target gene (Cel) as well as the reference genes ( $\mathrm{GyrB}$, Pfo and RecA) for Paraclostridium sp. have not yet been described in the literature. Thus, these primers were designed and the sequences and length of the amplified fragments are shown in Table 5.

Reference genes are genes whose expression remains stable in different situations, and are those which are essential to cellular metabolism (Pfaffl, 2001). The GyrB gene encodes the DNA gyrase enzyme subunit D (Peeters and Willems, 2011); the Pfo gene encodes the pyruvate ferredoxin oxidoreductase enzyme that catalyzes the conversion of pyruvate to acetyl CoA (Salimi and Mahadevan, 2013); and the RecA gene encodes the recombinase A enzyme (Liu et al., 2013).

Thus, the three chosen genes are essential for Paraclostridium metabolism and were tested for expression stability according to the RefFinder tool (Xie et al., 2012), which combines the geometric means of stability values calculated by the BestKeeper algorithms (Pfaffl et al., 2004), NormFinder (Andersen et al., 2004), GeNorm (Vandesompele et al., 2002) and Delta CT comparative method (Silver et al., 2006), creating a comprehensive classification. According to Bestkeeper, NormFinder,

A)

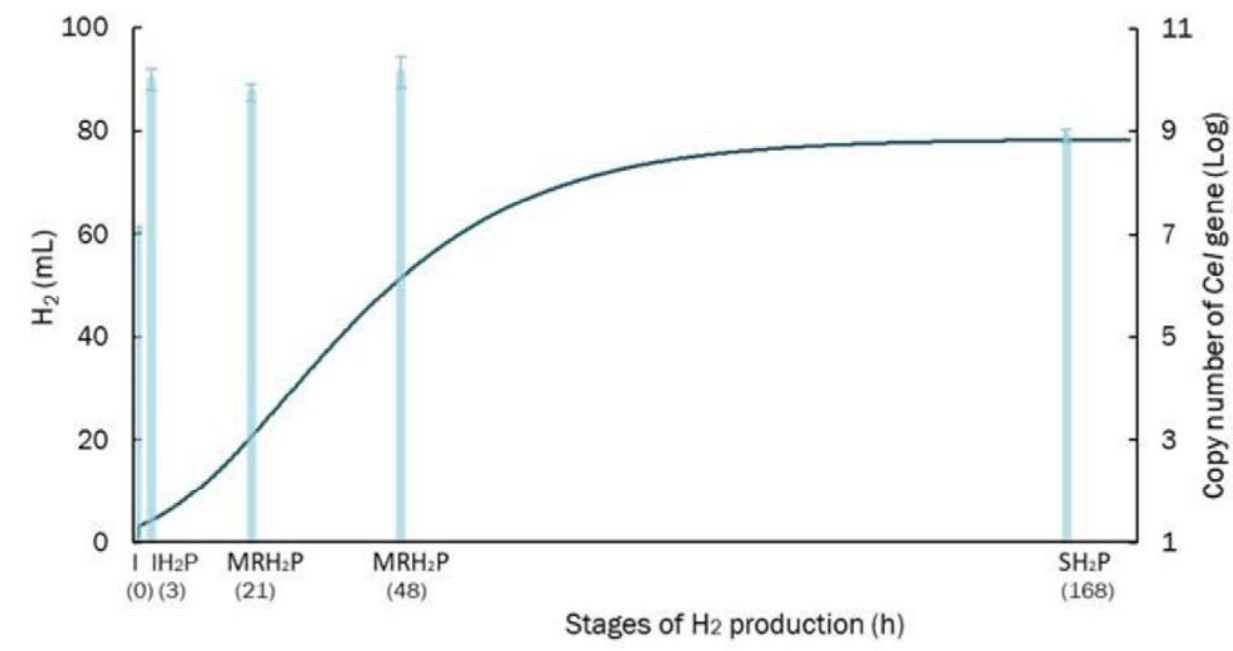

- Hydrogen production (Gompertz Mod) with cellulose copy number of cel gene

B)

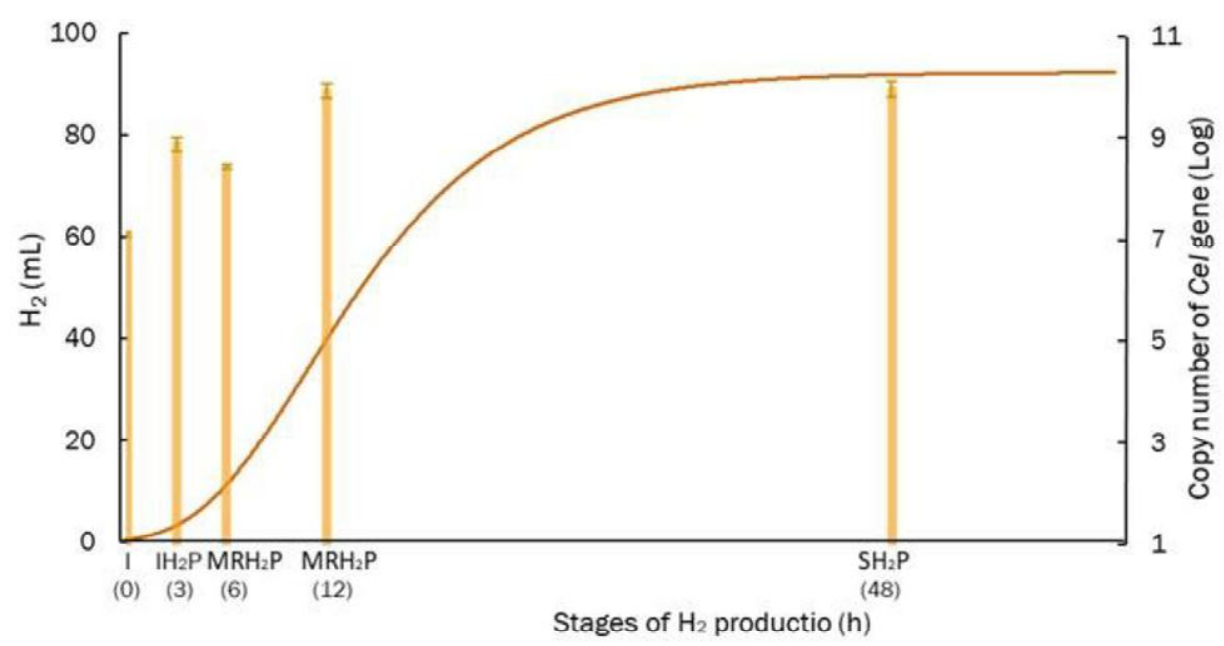

- Hydrogen production (Gompertz Mod) with SCB

Copy number of cel gene

Fig. 10. Cumulative $\mathrm{H}_{2}$ production ( $\mathrm{mL}$ ) and copy number of the gene Cel of Paracolstridium sp. CR4 in the cellulose (A) and SCB (B) fermentation reactors, according to the $\mathrm{H}_{2}$ production stages: Initial (I); initial $\mathrm{H}_{2}$ production $\left(\mathrm{IH}_{2} \mathrm{P}\right)$, maximum $\mathrm{H}_{2}$ production rate $\left(\mathrm{MRH}_{2} \mathrm{P}\right)$ and $\mathrm{H}_{2}$ production stabilization $\left(\mathrm{SH}_{2} \mathrm{P}\right)$. 
Delta Ct and RefFinder analysis, Pfo was obtained as the most stable gene (Fig. 9), and was chosen as a reference for the relative quantification of the target Cel gene.

\subsection{Absolute quant fication}

For absolute quantification, Eq. (7) was used, generated from the standard curve of the number of quantification cycles (Cq) as a function of the Log of the target gene copy number $(\mathrm{CN})$, correlation coefficient $\left(\mathrm{R}^{2}\right)$ of 0.9942 . The $\mathrm{CN}$ of Cel represents the cellular abundance of Paraclostridium sp. CR4.

CN $\quad-0 ; 2915$ Cq $\quad 99 ; 499$

The copy number of Paraclostridium sp. CR4 according to the $\mathrm{H}_{2}$ production stages from SCB cellulose are shown in Fig. 10.

In reactors with cellulose and Paraclostridium sp. CR4 yielded $1.3 \times 10^{7}$ (Initial), $1.2 \times 10^{10}\left(\mathrm{IH}_{2} \mathrm{P}\right)$ and $1.8 \times 10^{10} \mathrm{CN}$ at the highest $\mathrm{H}_{2}$ production stage $\left(\mathrm{MRH}_{2} \mathrm{~S}\right)$, which had higher cell growth. However in the $\mathrm{H}_{2}$ production stabilization stage $\left(\mathrm{SH}_{2} \mathrm{P}\right)$, a lower $\mathrm{CN}$ of $8.4 \times 10^{8}$ was observed. In SCB reactors, the increasing copy number of Cel gene was obtained throughout the experiment; i.e., $\mathrm{CN}$ of $1.3 \times 10^{7}$ (Initial), $7.9 \times 10^{8}\left(\mathrm{IH}_{2} \mathrm{P}\right), 8.4 \times 10^{9}$ in the highest $\mathrm{H}_{2}$ production stage $\left(\mathrm{MRH}_{2} \mathrm{P}\right)$ and $9.3 \times 10^{9}$ during the $\mathrm{H}_{2}$ production stabilization stage $\left(\mathrm{SH}_{2} \mathrm{P}\right)$. Therefore, in both cellulose and $\mathrm{SCB}$ reactors, favorable bacterial community dynamics were observed by increasing the copy number.

Pugazhendhi et al. (2017) obtained $\mathrm{CN}$ from $10^{9}$ to $10^{10}$ for C. butyricum in a fixed bed reactor with different hydraulic detention times ( 1.5 to $12 \mathrm{~h}$ ) to produce $\mathrm{H}_{2}$ from glucose. C. butyricum was the dominant species in all reactors examined, with over $91 \%$ of all bacteria. In the present study with pure culture of Paraclostridium sp. CR4, $10^{9}$ to $10^{10}$ were obtained with cellulose and SCB.

\subsection{Relative quant fication of gene expression}

According to relative quantification, changes in target gene mRNA levels of Cel were determined, relative to the levels of another stable

A)

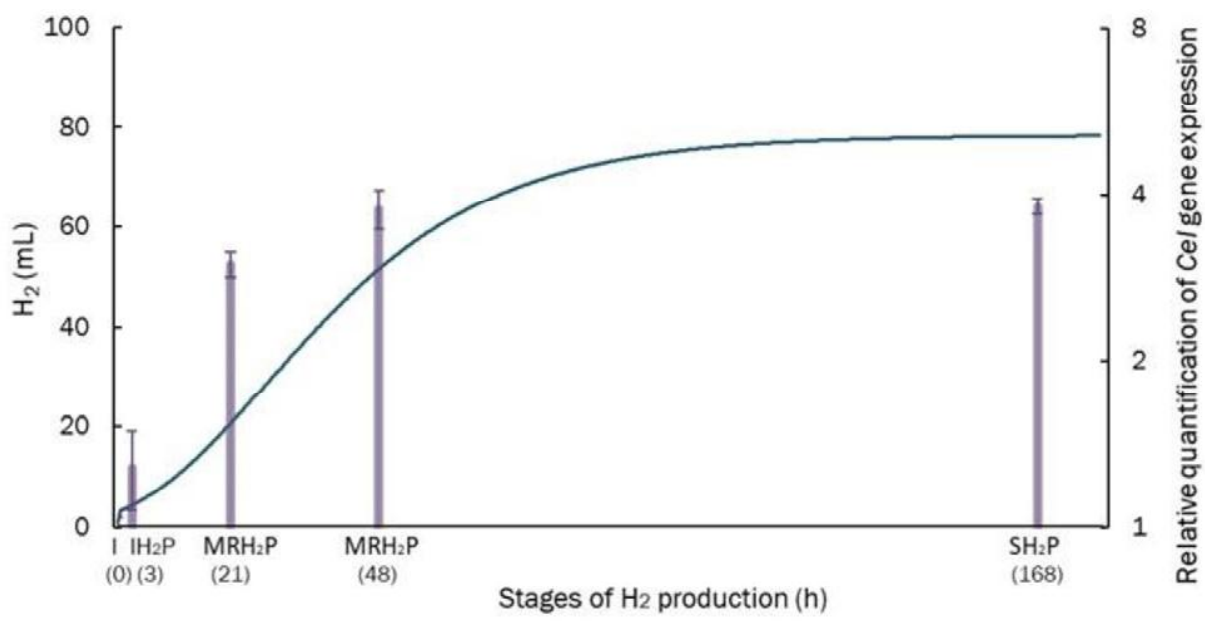

- Hydrogen production (Gompertz Mod) with cellulose aRelative quantification

B)

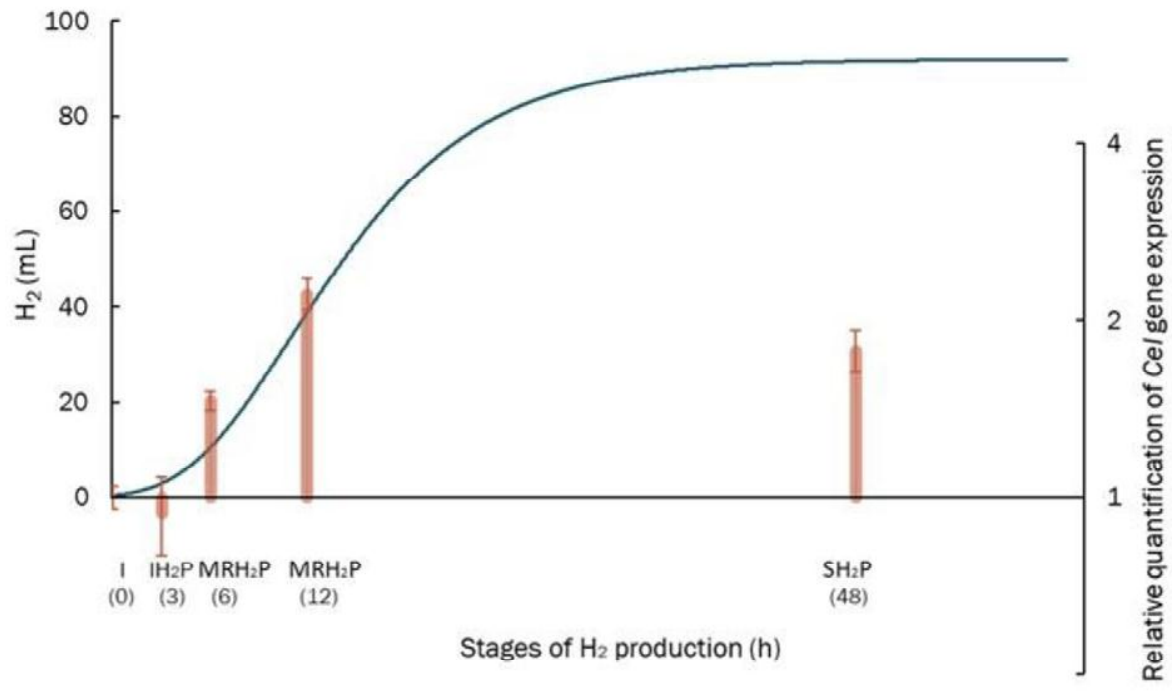

- Hydrogen production (Gompertz Mod) with SCB

Relative quantification

Fig. 11. Accumulated hydrogen production $(\mathrm{mL})$ and relative quantification of the expression of the Cel gene of Paracolstridium sp. CR4 in the fermentative reactors with cellulose as substrate $(A)$ and with SCB as substrate (B), according to the $\mathrm{H}_{2}$ production stages: Initial (I); initial $\mathrm{H}_{2}$ production $\left(\mathrm{IH}_{2} \mathrm{P}\right)$, maximum $\mathrm{H}_{2}$ production rate $\left(\mathrm{MRH} \mathrm{H}_{2} \mathrm{P}\right)$ and $\mathrm{H}_{2}$ production stabilization $\left(\mathrm{SH}_{2} \mathrm{P}\right)$. 
expression mRNA (reference gene, Pfo) and also normalized to a control group (time zero).

Thus, in reactors with cellulose substrate, the expression of the Cel gene increased during the $\mathrm{H}_{2}$ production stages. $\mathrm{In}_{2} \mathrm{P}$ the gene expression was 1.3 times higher than the Initial stage, and 3.0 and 3.8 times higher in $\mathrm{MRH}_{2} \mathrm{P}$ and $\mathrm{SH}_{2} \mathrm{P}$, respectively (Fig. 11A).

Kuo et al. (2012) observed that the hydrolysis of cellulosic material was the limiting factor for the fermentative production of $\mathrm{H}_{2}$ and methane in two-phase sequential reactors fed with kitchen waste and napier grass. Bio-augmentation with Clostridium sp. in the first stage favored substrate hydrolysis and $\mathrm{H}_{2}$ production. The authors reported that Clostridium sp. inoculated in the first stage reactor was also transferred to the second stage and favored further substrate degradation and subsequent methane production. According to the quantitative analysis of the present study, gene expression may also favor second stage hydrolysis, since the Cel gene was more transcribed in the final stages of $\mathrm{H}_{2}$ production $\left(\mathrm{MRH}_{2} \mathrm{P}\right.$ and $\left.\mathrm{SH}_{2} \mathrm{P}\right)$ than in the initial $\mathrm{H}_{2}$ production stage $\left(\mathrm{IH}_{2} \mathrm{P}\right)$.

In reactors with $\mathrm{SCB}$ as substrate, it was observed that even with increasing $\mathrm{CN}$ in $\mathrm{IH}_{2} \mathrm{P}$, lower gene expression was obtained in this stage (0.94) and higher during the $\mathrm{MRH}_{2} \mathrm{P}$ (2.2) and $\mathrm{SH}_{2} \mathrm{P}$ (1.78) stages when compared to the initial stage (1.0).

The initial concentration of soluble sugars in SCB reactors may have influenced Cel gene expression, since sugars released during hydrolysis may inhibit cellulase production (Petitdemange et al., 1992). Paraclostridium sp., as well as C. cellulolyticum studied by Petitdemange et al. (1992), may have a cellulolytic enzyme system subject to end-product regulation, in which soluble sugars may inhibit cellulase production.

The initial concentration of soluble sugars in the hydrothermally pretreated SCB reactors was $2.6 \mathrm{~g} / \mathrm{L}$, and lower concentrations were observed in the consecutive $\mathrm{H}_{2}$ production stages $(1.5,1.4$ and $1.2 \mathrm{~g} / \mathrm{L}$ in $\mathrm{IH}_{2} \mathrm{P}, \mathrm{MRH}_{2} \mathrm{P}$ and $\mathrm{SH}_{2} \mathrm{P}$, respectively). In the initial hydrogen production stage $\left(\mathrm{IH}_{2} \mathrm{P}\right)$ there was no expression of the Cel gene, so the production of $\mathrm{H}_{2}$ during this period may have been due to the fermentation of soluble sugars released from the hydrothermal pretreatment of SCB.

During the $\mathrm{MRH}_{2} \mathrm{P}$ stage, with lower sugar concentration $(1.4 \mathrm{~g} / \mathrm{L})$ the gene expression was higher (2.2 times) than in $\mathrm{IH}_{2} \mathrm{P}$, expressing more cellulases for substrate hydrolysis and fermentation of sugars in $\mathrm{H}_{2}(92.0 \mathrm{~mL})$ and organic acids (8.5 g/L) (Fig. 12).

\section{Conclusion}

Cellulolytic and fermentative bacteria similar to Paraclostridium sp. CR4 were isolated from sugarcane bagasse (SCB) and used as inoculum for the fermentative production of $\mathrm{H}_{2}$ from glucose ( $162.4 \mathrm{~mL}$ ), cellulose $(78.4 \mathrm{~mL})$ and SCB. The pretreatment applied to SCB favored hydrolysis and fermentation, as $92.0,62.5$ and $51.4 \mathrm{~mL}$ of $\mathrm{H}_{2}$ were obtained from hydrothermally pretreated SCB, heat pretreated SCB and in natura SCB, respectively. Metabolic route change was observed according to the substrate, that is, was by the acetic route with glucose (N46\%); and by the butyric route with cellulose (N44\%), and SCB (N62\%).

The copy numbers $(\mathrm{CN})$ of Paraclostridium in cellulose reactors was higher during the initial stages of $\mathrm{H}_{2}$ production, and lower during the stationary $\mathrm{H}_{2}$ production stage, while the expression of the Cel gene increased in all these stages. In SCB reactors, even with increased CN of Paraclostridium in all $\mathrm{H}_{2}$ production stages, the Cel gene expression was higher only during the maximum rate of $\mathrm{H}_{2}$ production. The amount of soluble sugars in the medium was inhibitory for enzymatic expression, since there was gene expression only in the stages with sugars lower than $1.4 \mathrm{~g} / \mathrm{L}$. Thus, it is possible that Paraclostridium sp. CR4 has a cellulolytic enzyme system subject to end product regulation.

Stage of initial $\mathrm{H}_{2}$ production $\left(\mathrm{IH}_{2} \mathrm{P}\right)$

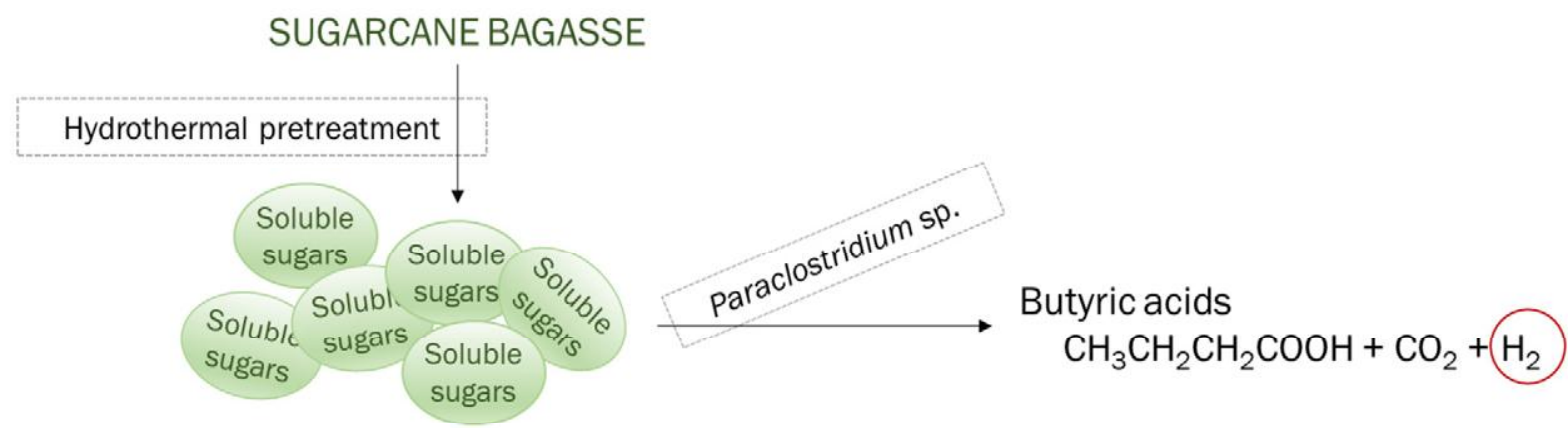

Stage of maximum rate of $\mathrm{H}_{2}$ production $\left(\mathrm{MRH}_{2} \mathrm{P}\right)$

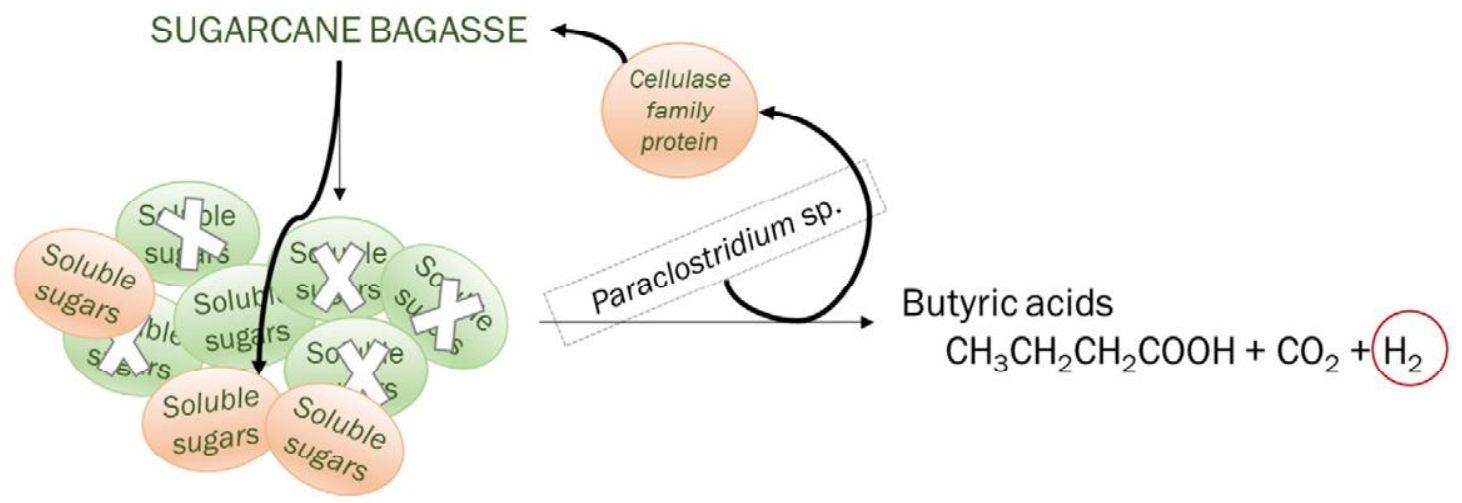

Fig. 12. Bioconversion of pretreated sugarcane bagasse into hydrogen and butyric acid by Paraclostridium sp. CR4. 
Paraclostridium sp. CR4 hydrolyzes and ferments cellulose, and can be used as inoculum in fermentative reactors for the production of $\mathrm{H}_{2}$ from different cellulosic residues, mainly SCB. In reactors with mixed inoculum, bioaugmentation with Paraclostridium sp. CR4 can increase the hydrolysis step of cellulosic waste digestion and favor conversion to other products of biotechnological interest, such as organic acids and biogas.

\section{Declaration of competing interest}

The authors declare that they have no known competing financial interests or personal relationships that could have appeared to influence the work reported in this paper.

\section{Acknowledgements}

This work was supported by the Conselho Nacional de Desenvolvimento Cientifico e Tecnológico (CNPq, Process no. 150.446/ 2018-7) and Fundação de Amparo Pesquisa do Estado de São Paulo (FAPESP, Process no. 2015/06246-7and 2018/26470-7).

\section{Appendix A. Supplementary data}

Supplementary data to this article can be found online at https://doi. org/10.1016/j.scitotenv.2020.136868.

\section{References}

Ahmad, F., Silva, E.L, Varesche, M.B.A., 2018. Hydrothermal processing of biomass for anaerobic digestion a review. Renew. Sust. Energ. Rev. 98, 108 124. https://doi.org/ 10.1016/j.rser.2018.09.008.

Andersen, C.L, Jensen, J.L., Ørntoft, T.F., 2004. Normalization of real-time quantitative reverse transcription-PCR data: a model-based variance estimation approach to identify genes suited for normalization, applied to bladder and colon cancer data sets. Cancer Res. 64, 52455250

Baroi, G.N., Baumann, I., Westermann, P., Gavala, H.N., 2015. Butyric acid fermentation from pretreated and hydrolysed wheat straw by an adapted Clostridium tyrobutyricum strain. Microb. Biotechnol. 8, 874 882. https://doi.org/10.1111/17517915.12304

Béra-maillet, C., Mosoni, P., Kwasiborski, A., Suau, F., Ribot, Y., Forano, E., 2009. Development of a RT-qPCR method for the quantification of Fibrobacter succinogenes S85 glycoside hydrolase transcripts in the rumen content of gnotobiotic and conventiona sheep. J. Microbiol. Methods 77, 8 16. https://doi.org/10.1016/j.mimet.2008.11.009.

Binod, P., Janu, K.U., Sindhu, R., 2011. Hydrolysis of lignocellulosic biomass for bioethano production. In: Press, A. (Ed.), Biofuels Alternative Feedstocks and Conversion Process. Elsevier Inc., Burlington, pp. 229 250. https://doi.org/10.1016/B978-0-12 385099-7.00010-3.

Braga, J.K., Motteran, F., Sakamoto, I.K., Varesche, M.B.A., 2018. Bacterial and archaeal community structure involved in biofuels production using hydrothermal- and enzymatic-pretreated sugarcane bagasse for an improvement in hydrogen and methane production. Sustain. Energy Fuels 2, 2644 2660. https://doi.org/10.1039/ C8SE00312B.

Braga, J.K., Abreu, A.A., Motteran, F., Alcina, M., Madalena, M., Maria, A., Varesche, B.A. 2019. Hydrogen production by Clostridium cellulolyticum a cellulolytic and hydrogen-producing bacteria using sugarcane bagasse. Waste Biomass Valoriz. 10 827 837. https://doi.org/10.1007/s12649-017-0105-9.

Brankatschk, R., Bodenhausen, N., Zeyer, J., Bürgmann, H., 2012. Simple absolute quantification method correcting for quantitative PCR efficiency variations for microbial community samples. Appl. Environ. Microbiol. 78, 4481 4489. https://doi.org/10.1128/ AEM.07878-11.

Cai, G., Jin, B., Saint, C., Monis, P., 2010. Metabolic flux analysis of hydrogen production network by Clostridium butyricum W5: effect of $\mathrm{pH}$ and glucose concentrations. Int. J. Hydrog. Energy 35, 6681 6690. https://doi.org/10.1016/j.ijhydene.2010.04.097.

Chi, X., Li, J., Wang, X., Zhang, Y., Leu, S.Y., Wang, Y., 2018. Bioaugmentation with Clostridium tyrobutyricum to improve butyric acid production through direct rice straw bioconversion. Bioresour. Technol. 263, 562 568. https://doi.org/10.1016/j biortech.2018.04.120.

Deng, Y., Huang, Z., Ruan, W., Zhao, M., Miao, H., Ren, H., 2017. Co-inoculation of cellulolytic rumen bacteria with methanogenic sludge to enhance methanogenesis of rice straw. Int. Biodeterior. Biodegrad. 117, 224 235. https://doi.org/10.1016/j.ibiod.2017.01.017.

Desvaux, M., 2005. Clostridium cellulolyticum: model organism of mesophilic cellulolytic clostridia. FEMS Microbiol. Rev. 29, 741 764. https://doi.org/10.1016/j.femsre.2004.11.003.

Díaz, V.H.G., Willis, M.J., 2019. Ethanol production using Zymomonas mobilis: development of a kinetic model describing glucose and xylose co-fermentation. Biomass Bioenergy 123, 41 50. https://doi.org/10.1016/j.biombioe.2019.02.004.

Dollhofer, V., Martin, T., Dorn-in, S., Bauer, J., Lebuhn, M., 2016. Development of three specific PCR-based tools to determine quantity, cellulolytic transcriptional activity and phylogeny of anaerobic fungi. J. Microbiol. Methods 127, 28 40. https://doi.org/ 10.1016/j.mimet.2016.05.017.

DSM, 1991. Scientific Services of Culture Collections - Coloração de Gram. Curso Minist. na Fundação Trop. Pesqui. e Tecnol. André Tosello , Campinas.

DuBois, M., Gilles, K.A., Hamilton, J.K. Rebers, P.A., Smith, F., 1956. Colorimetric method for determination of sugars and related substances. Anal. Chem. 28, 350356. https://doi.org/10.1021/ac60111a017.

Galbe, M., Zacchi, G., 2012. Pretreatment: the key to efficient utilization of lignocellulosic materials. Biomass Bioenergy 46, 70 78. https://doi.org/10.1016/j.biombioe.2012.03.026.

Geng, A., He, Y., Qian, C., Yan, X., Zhou, Z., 2010. Effect of key factors on hydrogen production from cellulose in a co-culture of Clostridium thermocellum and Clostridium thermopalmarium. Bioprocess Technol. J. 101 (11), 4029 4033. https://doi.org/ 10.1016/j.biortech.2010.01.042

Giallo, J., Gaudin, C., Belaich, J., 1985. Metabolism and solubilization of cellulose by Clostridium cellulolyticum HIO. Appl. Environ. Microbiol. 49, 12161221.

Guo, X.M., Trably, E., Latrille, E., Carrre, H., Steyer, J.P., 2010. Hydrogen production from agricultural waste by dark fermentation: a review. Int. J. Hydrog. Energy 35, 10660 10673. https://doi.org/10.1016/j.ijhydene.2010.03.008.

Guo, Y.C., Dai, Y., Bai, Y.X., Li, Y.H., Fan, Y.T., Hou, H.W., 2014. Co-producing hydrogen and methane from higher-concentration of corn stalk by combining hydrogen fermentation and anaerobic digestion. Int. J. Hydrog. Energy 39, 14204 14211. https://doi.org/ 10.1016/j.ijhydene.2014.02.089.

Gupta, P., Samant, K., Sahu, A., 2012. Isolation of cellulose-degrading bacteria and determination of their cellulolytic potential. Int. J. Microbiol. 2012. https://doi.org/ $10.1155 / 2012 / 578925$.

Gupta, M., Velayutham, P., Elbeshbishy, E., Hafez, H., Khafipour, E., Derakhshani, H., El Naggar, M.H., Levin, D.B., Nakhla, G., 2014. Co-fermentation of glucose, starch, and cellulose for mesophilic biohydrogen production. Int. J. Hydrog. Energy 39, 20958 20967. https://doi.org/10.1016/j.ijhydene.2014.10.079.

Hames, B., Ruiz, R., Scarlata, C., Sluiter, A., Sluiter, J., Templeton, D., 2008. Preparation of Samples for Compositional Analysis.

Herbert, D., Philipps, P.J., Strange, R.E., 1971. Carbohydrate analysis. Methods Enzymol. 5 265277.

Hwang, Y., Sivagurunathan, P., Lee, M., Yun, Y., Song, Y., Kim, D., 2018. Enhanced hydrogen fermentation by zero valent iron addition. Int. J. Hydrog. Energy, 18 https://doi.org/ 10.1016/j.ijhydene.2018.06.015.

Juturu, V., Wu, J.C., 2014. Microbial cellulases: engineering, production and applications. Renew. Sust. Energ. Rev. 33, 188 203. https://doi.org/10.1016/j.rser.2014.01.077.

Kumar, R., Singh, S., Singh, O.V., 2008. Bioconversion of lignocellulosic biomass: biochemical and molecular perspectives. J. Ind. Microbiol. Biotechnol. 35, 377 391. https://doi. org/10.1007/s10295-008-0327-8

Kumar, S., Stecher, G., K, T., 2016. MEGA 7: Molecular Evolutionary Genetics Analysis version 7.0 for bigger datasets. Mol. Biol. Evol. 33, 18701874

Kuo, W.C., Chao, Y.C., Wang, Y.C., Cheng, S.S., 2012. Bioaugmentation strategies to improve cellulolytic and hydrogen producing characteristics in CSTR intermittent fed with vegetable kitchen waste and napiergrass. Energy Procedia 29, 82 91. https://doi. org/10.1016/j.egypro.2012.09.011.

Kutsuna, R., Tomida, J., Miyoshi-akiyama, T., Mori, K, Hayashi, M Morita, Y., Tanaka, K. Kawamura, Y., 2018. Description of Paraclostridium bifermentans subsp. muricolitidis subsp. nov., emended description of Paraclostridium bifermentans (Sasi Jyothsna et al., 2016), and creation of Paraclostridium bifermentans subsp. bifermentans subsp. nov. Microbiol. Immunol. 63, 1 10. https://doi.org/10.1111/1348-0421.12663.

Lane, D.J., 1991. 16S/23S rRNA sequencing. In: Stackenbrandt, E., Goodfellow, W. (Eds.), Nucleic Acid Techniques in Bacterial Systematics. John Wiley and Sons, New York, pp. 115148

Lay, J.J., 2001. Biohydrogen generation by mesophilic anaerobic fermentation of microcrystalline cellulose. Biotechnol. Bioeng. 74, 280 287. https://doi.org/10.1002/ bit.1118.

Liu, J., Tan, Y., Yang, X., Chen, X., Li, F., 2013. Evaluation of Clostridium ljungdahlii DSM 13528 reference genes in gene expression studies by qRT-PCR. J. Biosci. Bioeng. 116, 460 464. https://doi.org/10.1016/j.jbiosc.2013.04.011.

Lu, H., Lee, P.K.H., 2015. Effects of cellulose concentrations on the syntrophic interaction between Clostridium cellulovorans 743B and Rhodopseudomonas palustris CGA009 in coculture fermentation for biohydrogen production. Int. J. Hydrog. Energy 40, 11800 11808. https://doi.org/10.1016/j.ijhydene.2015.05.135.

Luo, H., Yang, R., Zhao, Y., Wang, Z., Liu, Z., Huang, M., Zeng, Q., 2018. Recent advances and strategies in process and strain engineering for the production of butyric acid by microbial fermentation. Bioresour. Technol. 253, 343 354. https://doi.org/10.1016/j. biortech.2018.01.007.

Masset, J., Calusinska, M., Hamilton, C., Hiligsmann, S., Joris, B., Wilmotte, A., Thonart, P., 2012. Fermentative hydrogen production from glucose and starch using pure strains and artificial co-cultures of Clostridium spp. pp. 115.

Mazareli, R.C.S., Sakamoto, I.K., Silva, E.L., Varesche, M.B.A., 2019. Bacillus sp. isolated from banana waste and analysis of metabolic pathways in acidogenic systems in hydrogen production. J. Environ. Manag. 247, 178 186. https://doi.org/10.1016/j. jenvman.2019.06.040.

Mu, Y., Zheng, X., Yu, H., 2009. Determining optimum conditions for hydrogen production from glucose by an anaerobic culture using response surface methodology (RSM). Int. J. Hydrog. Energy 34, 7959 7963. https://doi.org/10.1016/j.ijhydene.2009.07.093.

Muñoz, C., Hidalgo, C., Zapata, M., Jeison, D., Riquelme, C., Rivas, M., 2014. Use of cellulolytic marine bacteria for enzymatic pretreatment in microalgal biogas production. Appl. Environ. Microbiol. 80, 4199 4206. https://doi.org/10.1128/AEM.00827-14.

Oh, H.J., Kim, K.Y., Lee, K.M., Lee, S.M., Gong, G., Oh, M.K., Um, Y., 2019. Enhanced butyric acid production using mixed biomass of brown algae and rice straw by Clostridium tyrobutyricum ATCC25755. Bioresour. Technol. 273, 446 453. https://doi.org/ 10.1016/j.biortech.2018.11.037. 
Ozkan, L., Erguder, T.H., Demirer, G.N., 2011. Effects of pretreatment methods on solubilization of beet-pulp and bio-hydrogen production yield. Int. J. Hydrog. Energy 36, 382 389. https://doi.org/10.1016/j.ijhydene.2010.10.006.

Pan, C.M., Fan, Y.T., Xing, Y., Hou, H.W., Zhang, M.L, 2008. Statistical optimization of process parameters on biohydrogen production from glucose by Clostridium sp. Fanp2. Bioresour. Technol. 99, 3146 3154. https://doi.org/10.1016/j.biortech.2007.05.055.

Peeters, K., Willems, A., 2011. The gyrB gene is a useful phylogenetic marker for exploring the diversity of Flavobacterium strains isolated from terrestrial and aquatic habitats in Antarctica. FEMS Microbiol. Lett. 321, 130 140. https://doi.org/10.1111/j.15746968.2011.02326.x.

Petitdemange, E., Tchunden, T., Vallés, S., Pirson, H., Raval, G., Gay, R., 1992. Effect of carbon sources on cellulase production by Clostridium cellulolyticum. Biomass Bioenergy 3,393402

Pfaffl, M.W., 2001. A new mathematical model for relative quantification in real-time RT PCR. Nucleic Acids Res. 29, 1621.

Pfaffl, M.W., Tichopad, A., Prgomet, C., Neuvians, T.P., 2004. Determination of stable housekeeping genes, differentially regulated target genes and sample integrity: BestKeeper Excel-based tool using pair-wise correlations. Biotechnol. Lett. 26, 509515

Prakasham, R.S., Brahmaiah, P., Sathish, T., Rao, K.R.S.S., 2009. Fermentative biohydrogen production by mixed anaerobic consortia: impact of glucose to xylose ratio. Int. J. Hydrog. Energy 34, 9354 9361. https://doi.org/10.1016/j.ijhydene.2009.09.104

Pugazhendhi, A., Anburajan, P., Park, J.H., Kumar, G., Sivagurunathan, P., Kim, S.H., 2017. Process performance of biohydrogen production using glucose at various HRTs and assessment of microbial dynamics variation via q-PCR. Int. J. Hydrog. Energy 42 , 27550 27557. https://doi.org/10.1016/j.ijhydene.2017.06.184.

Quemeneur, M., Hamelin, J., Benomar, S., Guidici-Orticoni, M.T., Latrille, E., Steyer, J.P., Trably, E., 2011. Changes in hydrogenase genetic diversity and proteomic patterns in mixed-culture dark fermentation of mono- , di- and. Int. J. Hydrog. Energy 36, 11654 11665. https://doi.org/10.1016/j.ijhydene.2011.06.010.

Rabelo, S.C., Carrere, H., Maciel Filho, R., Costa, aC, 2011. Production of bioethanol, methane and heat from sugarcane bagasse in a biorefinery concept. Bioresour. Technol. 102, 7887 7895. https://doi.org/10.1016/j.biortech.2011.05.081.

Rabelo, C.A.B.S., Soares, L.A., Varesche, M.B.A., 2017. Comparison and evaluation of hydrogen and methane productions from hydrothermal pretreated sugarcane bagasse by two microbial consortium. Austin Clin. Microbiol. 2, 16.

Rabelo, C.A.B.S., Soares, L.A., Sakamoto, I.K., Silva, E.L., Varesche, M.B.A., 2018a. Optimization of hydrogen and organic acids productions with autochthonous and allochthonous bacteria from sugarcane bagasse in batch reactors. J. Environ. Manag. 223, 952 963. https://doi.org/10.1016/j.jenvman.2018.07.015.

Rabelo, C.A.B.S., Soares, L.A., Sakamoto, I.K., Varesche, M.B.A., 2018b. Bioconversio of cellulose into hydrogen, biogas and organic acids using microbial consortium from a pulp and paper mill wastwater treatment plant. Quim Nova 41, 169175.

Rainey, F.A., 2009. Class Clostridia. In: Brenner, D., Krieg, N., Staley, J. (Eds.), Bergey s Manual of Sistematic Bacteriology Volume Three. Springer, New York.

Ramachandran, U., Wrana, N., Cicek, N., Sparling, R., Levin, D.B., 2008. Hydrogen production and end-product synthesis patterns by Clostridium termitidis strain CT1112 in batch fermentation cultures with cellobiose or a-cellulose. Int. J. Hydrog. Energy 33, 7006 7012. https://doi.org/10.1016/j.ijhydene.2008.09.022.

Ratti, R.P., Delforno, T.P., Sakamoto, I.K., Varesche, M.B.A., 2015. Thermophilic hydrogen production from sugarcane bagasse pretreated by steam explosion and alkaline delignification. Int. J. Hydrog. Energy 40, 6296 6306. https://doi.org/10.1016/j. ijhydene.2015.03.067.

Ren, Z., Ward, T.E., Logan, B.E., Regan, J.M., 2007. Characterization of the cellulolytic and hydrogen-producing activities of six mesophilic Clostridium species. J. Appl. Microbiol. 103, 2258 2266. https://doi.org/10.1111/j.1365-2672.2007.03477.x.

Ren, N., Cao, G., Wang, A., Lee, D., 2008. Dark fermentation of xylose and glucose mix using isolated Thermoanaerobacterium thermosaccharolyticum W16. Int. J. Hydrog. Energy 33, 6124 6132. https://doi.org/10.1016/j.ijhydene.2008.07.107.

Salimi, F., Mahadevan, R., 2013. Characterizing metabolic interactions in a clostridial coculture for consolidated bioprocessing. BMC Biotechnol. 13, 1 9. https://doi.org/ $10.1186 / 1472-6750-13-95$.

Saratale, G.D., Chen, S.D., Lo, Y.C., Saratale, R.G., Chang, J.S., 2008. Outlook of biohydrogen production from lignocellulosic feedstock using dark fermentation - a review. J. Sci. Ind. Res. (India) 67, 962979.
Sasi Jyothsna, T.S., Tushar, L., Sasikala, C., Ramana, C.V., 2016. Paraclostridium benzoelyticum gen. nov., sp. nov., isolated from marine sediment and reclassification of Clostridium bifermentans as Paraclostridium bifermentans comb. nov. proposal of a new genus Paeniclostridium gen. nov. to accommodate Clostridium sord. Int. J. Syst. Evol. Microbiol. 66, 1268 1274. https://doi.org/10.1099/ijsem.0.000874.

Shrestha, S., Fonoll, X., Kumar, S., Raskin, L., 2017. Biological strategies for enhanced hydrolysis of lignocellulosic biomass during anaerobic digestion: current status and future perspectives. Bioresour. Technol. 245, 1245 1257. https://doi.org/10.1016/j. biortech.2017.08.089.

Silver, N., Best, S., Jiang, J., Thein, S.L., 2006. Selection of housekeeping genes for gene expression studies in human reticulocytes using real-time PCR. BMC Mol. Biol. 9, 19. https://doi.org/10.1186/1471-2199-7-33.

Singh, K.M., Pandya, P.R., Tripathi, A.K., Patel, G.R., Parnerkar, S., 2014. Study of rumen metagenome community using qPCR under different diets. Meta Gene 2, 191199. https://doi.org/10.1016/j.mgene.2014.01.001.

Soares, L.A., Braga, J.K., Motteran, F., Sakamoto, I.K., Silva, E.L., Varesche, M.B.A., Engineering, S., 2017. Design and optimization of hydrogen production from sugarcane bagasse hydrothermally pretreated using response surface methodology. Water Sci. Technol. 76, 95 105. https://doi.org/10.2166/wst.2017.183.

Talia, P., Sede, S.M., Campos, E., Rorig, M., Principi, D., Tosto, D., Hopp, H.E., Grasso, D. Cataldi, A., 2012. Biodiversity characterization of cellulolytic bacteria present on native Chaco soil by comparison of ribosomal RNA genes. Res. Microbiol. 163 221 232. https://doi.org/10.1016/j.resmic.2011.12.001.

Tamura, K., Nei, M., 1993. Estimation of the number of nucleotide substitutions in the control regionof mitochondrial DNA in humans and chimpanzees. Mol. Biol. Evol. 10, 512526.

Tantayotai, P., Pornwongthong, P., Muenmang, C., Phusantisampan, T., Sriariyanun, M., 2017. Effect of cellulase-producing microbial consortium on biogas production from lignocellulosic biomass. Energy Procedia 141, 180 183. https://doi.org/10.1016/j. egypro.2017.11.034.

Temudo, M.F., Kleerebezem, R., van Loosdrecht, M., 2007. Influence of the pH on (open) mixed culture fermentation of glucose: a chemostat study. Biotechnol. Bioeng. 98 69 79. https://doi.org/10.1002/bit.

UNICA S.P.S.A. 2019. A bioeletricidade da cana. URL. https://www.unica.com.br/wp-content/uploads/2019/07/UNICA-Bioeletricidade-julho2019-1.pdf (WWW Document).

Vandesompele, J., Preter, K.D., Poppe, B., Roy, N.V., Paepe, A.D., 2002. Accurate normalization of real-time quantitative RT-PCR data by geometric averaging of multiple internal control genes. Genome Biol. 3, 1 12.

Wang, M., Tsai, Y., Olson, B.H., Chang, J., 2008. Monitoring dark hydrogen fermentation performance of indigenous Clostridium butyricum by hydrogenase gene expression using RT-PCR and qPCR 33. 4730 4738. https://doi.org/10.1016/j.ijhydene.2008.06.048.

Wei, Y., Zhou, H., Zhang, J., Zhang, L., Geng, A., Liu, F., 2015. Insight into dominant cellulolytic bacteria from two biogas digesters and their glycoside hydrolase genes. PLoS One 10, 1 19. https://doi.org/10.1371/journal.pone.0129921.

Whitman, W.B., 2010. Volume three the Firmicutes. In: De Vos, P., Garrity, G.M., Jones, D. Krieg, N.R., Ludwig, W., Rainey, F.A., Schleifer, K.-H., Whitman, W.B. (Eds.), Bergey s Manual of Siytematic Bacteriology. Springer, New York.

Xie, F., Xiao, P., Chen, D., 2012. miRDeepFinder: a miRNA analysis tool for deep sequencing of plant small RNAs. Plant Mol. Biol. 80, 75 84. https://doi.org/10.1007/s11103-0129885-2.

Xu, J., Thomsen, M.H., Thomsen, A.B., 2010. Feasibility of hydrothermal pretreatment on maize silage for bioethanol production. Appl. Biochem. Biotechnol. 162, 3342. https://doi.org/10.1007/s12010-009-8706-9.

Yang, G., Wang, J., 2018. Enhancement of biohydrogen production from grass by ferrous ion and variation of microbial community. Fuel 233, 404 411. https://doi.org/ 10.1016/j.fuel.2018.06.067.

Yang, G., Yin, Y., Wang, J., 2019. Microbial community diversity during fermentative hydrogen production inoculating various pretreated cultures. Int. J. Hydrog. Energy 44, 13147 13156. https://doi.org/10.1016/j.ijhydene.2019.03.216.

Zhang, J.N., Li, Y.H., Zheng, H.Q., Fan, Y.T., Hou, H.W., 2015. Direct degradation of cellulosic biomass to bio-hydrogen from a newly isolated strain Clostridium sartagoforme FZ11. Bioresour. Technol. 192, 60 67. https://doi.org/10.1016/j.biortech.2015.05.034.

Zwietering, M.H., Jongenburger, L., Rombouts, F.M., Van t, R.K., 1990. Modeling of the bacterial growth curve. Appl. Environ. Microbiol. 56, 18751881. 